Review

\title{
The diversity of molecular mechanisms of carbonate biomineralization by bacteria
}

\author{
Sigrid Görgen ${ }^{1,3} \cdot$ Karim Benzerara ${ }^{1} \cdot$ Fériel Skouri-Panet ${ }^{1} \cdot$ Muriel Gugger $^{2} \cdot$ Franck Chauvat $^{3}$. \\ Corinne Cassier-Chauvat ${ }^{3}$
}

Received: 1 June 2020 / Accepted: 23 October 2020

(C) The Author(s) 2020 OPEN

\begin{abstract}
Although biomineralization of $\mathrm{CaCO}_{3}$ is widespread in Bacteria and Archaea, the molecular mechanisms involved in this process remain less known than those used by Eukaryotes. A better understanding of these mechanisms is crucial for a broad diversity of studies including those (i) aiming at assessing the role of bacteria in the geochemical cycles of $\mathrm{Ca}$ and $\mathrm{C}$, (ii) investigating the process of fossilization, and (iii) engineering applications using bacterially mediated $\mathrm{CaCO}_{3}$ mineralization. Different types of bacterially-mediated mineralization modes have been distinguished depending on whether they are influenced (by extracellular organic molecules), induced (by metabolic activity) or controlled (by specific genes). In the first two types, mineralization is usually extracellular, while it is intracellular for the two ascertained cases of controlled bacterial mineralization. In this review, we list a large number of cases illustrating the three different modes of bacterially-mediated $\mathrm{CaCO}_{3}$ mineralization. Overall, this shows the broad diversity of metabolic pathways, organic molecules and thereby microorganisms that can biomineralize $\mathrm{CaCO}_{3}$. Providing an improved understanding of the mechanisms involved and a good knowledge of the molecular drivers of carbonatogenesis, the increasing number of (meta)-omics studies may help in the future to estimate the significance of bacterially mediated $\mathrm{CaCO}_{3}$ mineralization.
\end{abstract}

Keywords Prokaryote $\cdot$ Biologically-influenced mineralization · Biologically-induced mineralization · Biologicallycontrolled mineralization · Alkalinity engine $\cdot$ MICP $\cdot$ Heterogeneous nucleation · ACC · Exopolymeric substances

\author{
Abbreviations \\ ACC Amorphous calcium carbonate \\ CA Carbonic anhydrase \\ CEMOVIS Cryo-electron microscopy of vitreous section \\ EPS Extracellular polymeric substances \\ iACC Intracellular amorphous Ca-carbonate
}

Electronic supplementary material The online version of this article (https://doi.org/10.1007/s43939-020-00001-9) contains supplementary material, which is available to authorized users.

\footnotetext{
$\triangle$ Karim Benzerara, karim.benzerara@sorbonne-universite.fr; Sigrid Görgen, sigrid.gorgen@sorbonne-universite.fr; Fériel Skouri-Panet, feriel.skouri-panet@sorbonne-universite.fr; Muriel Gugger, muriel.gugger@pasteur.fr; Franck Chauvat, Franck.CHAUVAT@cea.fr; Corinne Cassier-Chauvat, Corinne.CASSIER-CHAUVAT@cea.fr | ${ }^{1}$ Institut de Minéralogie, de Physique Des Matériaux Et de Cosmochimie, Sorbonne Université, UMR CNRS 7590, Muséum National D'Histoire Naturelle, Paris, France. ${ }^{2}$ Collection Des Cyanobactéries, Institut Pasteur, 75724 Paris Cedex 15, France. ${ }^{3}$ Université Paris-Saclay, CEA, CNRS, Institute for Integrative Biology of the Cell (I2BC), 91198 Gif-sur-Yvette, France.
} 


\section{Background}

Here, we define biomineralization in the broadest sense as the process by which organisms form minerals, i.e. including both indirect and controlled formation pathways. Although biomineralization has been extensively studied in eukaryotes, it is also widespread among Bacteria and Archaea [1, 2].

Bacterial biomineralization has been known for more than a century. Ehrenberg discovered the iron-oxidizer Gallionella ferruginea in 1838, which biomineralizes iron oxyhydroxides on extracellular stalks [3]. Schewiakoff in 1893 described intracellular biomineralization by Achromatium oxaliferum, although at that time the taxonomic affiliation of this giant sulfur bacterium was uncertain and the identity of the biominerals misidentified [4]. In 1903, Nadson showed that calcium carbonate deposits in Lake Veisowe, Russia, could have originated from bacterial activity [5]. Later on, Drew in 1911 suggested that marine denitrifying bacteria played an active role in the precipitation of calcium carbonates with a potential geological significance of this process [6]. Kalkowsky in 1908 coined the word stromatolite (Stromatolith) insisting on the importance of microorganisms in the formation of these carbonate rocks [7], which are now known to be populated by a high diversity of microbes [8].

More recently, studies have strengthened the idea that bacterial biomineralization is pervasive and very diverse. Boquet in 1973 showed that diverse soil bacteria produce calcium carbonates [9]. A broad diversity of carbonate mineral phases can be formed by bacteria including the different polymorphs of Ca-carbonates: calcite but also, aragonite [10] and vaterite [11], hydrated Ca-carbonates such as monohydrocalcite [12, 13], amorphous (Ca, Sr, Ba, Ra)-carbonates [14, 15], dolomite $\left(\mathrm{Ca}-\mathrm{Mg}-\mathrm{CO}_{3}\right)[16]$, hydromagnesite $\left(\mathrm{Mg}_{5}\left(\mathrm{CO}_{3}\right)_{4}(\mathrm{OH})_{2} \cdot 4 \mathrm{H}_{2} \mathrm{O}\right)[17]$, or siderite $\left(\mathrm{FeCO}_{3}\right)[18]$.

Diverse objectives have motivated studies about bacterial carbonate biomineralization (carbonatogenesis): (1) some studies aimed at quantifying the impact of bacteria on modern and ancient geochemical cycles of $\mathrm{C}$ and/or $\mathrm{Ca}[19,20]$. It has been convincingly argued that bacterial biomineralization has massively contributed to the formation of large-scale carbonate deposits all over Earth's history [20,21]. (2) Similarly, it has been suggested that bacterial biomineralization can favor fossilization and the preservation of traces of life in ancient rocks [22]. Consistently, bacterial carbonate biominerals are prone targets for searching traces of ancient life on Earth or Mars [23, 24]. For example, carbonate microbialites, which include stromatolites, are emblematic byproducts of bacterial biomineralization, considered as among the oldest traces of life [25-27]. (3) In addition, an active field of research aims at using bacterial carbonate biomineralization for diverse engineering applications. For example, the removal of polluting heavy metals or radionuclides (e.g. Ra, Sr) may be achieved by their co-precipitation with calcium carbonate by biomineralizing bacteria $[15,28]$. Alternatively, bacterial carbonate biomineralization has been proposed as a strategy for carbon capture and storage [29]. Microbially enhanced oil recovery by plugging highly permeable rocks with bacterial carbonate biominerals has also been considered [30, 31]. Finally, bacterial carbonate biomineralization can be used for stabilizing soils and sediments [32], and restoring weathered limestone and cement monuments [30,33]. More details on the use of microbially precipitated $\mathrm{CaCO}_{3}$ as biomaterials can be found in several recent review papers [34-38].

For all these basic and applied science applications, there are crucial needs to understand the mechanisms involved in the mediation of carbonate precipitation by bacteria. Mineral precipitation can be triggered by: (1) the increase of the saturation index of the solution surrounding cells with this mineral phase. In the case of carbonate mineral phases, the saturation index increases with calcium ion activity $\left(\mathrm{Ca}^{2+}\right)$ and carbonate ion activity $\left(\mathrm{CO}_{3}{ }^{2-}\right)$, hence bicarbonate ion activity $\left(\mathrm{HCO}_{3}{ }^{-}\right)$and $\mathrm{pH} ;$ (2) the decrease of the nucleation energy barrier. In that regard, some molecules produced by the cells act as preferential nucleation sites and favor heterogeneous nucleation $[39,40]$. Following these principles, different biomineralization pathways have been distinguished [41]. (a) Biologically influenced mineralization comprises cases when mineral precipitation is favored by nucleation on bacterially produced organic polymers, such as those composing cell surfaces or extracellular polymeric substances (EPS). In such cases, biomineralization occurs in already saturated solution and does not require the cells to be metabolically active. (b) Biologically induced mineralization encompasses all cases when the precipitation of carbonate mineral phases results from chemical modifications of the microenvironment surrounding cells induced by their metabolic activities. These chemical shifts mostly include an increase of $\mathrm{pH}$, or $\left[\mathrm{HCO}_{3}{ }^{-}\right]$ at constant $\mathrm{pH}$. This is termed the "alkalinity engine" [41]. (c) Biologically controlled mineralization groups cases when a specific, genetic control of some of the mineral precipitation steps (e.g. nucleation and/or growth) occurs. As detailed below, there are known cases of bacterial carbonatogenesis for all three classes. Alternatively, biomineralization pathways can be discriminated as active $v s$ passive based on whether they cost energy (they depend on metabolically active cells) or not (they need cells not necessarily alive). Lastly, biomineralization processes can be distinguished based on their 
localization respectively to the cell (intra- or extra-cellular). While bacterial carbonatogenesis has often been considered as extracellular, numerous environmentally significant bacteria perform intracellular biomineralization [42, 43].

Overall, to infer whether carbonatogenesis depends on specific genes (controlled mineralization), it is important to decipher the operating molecular mechanisms, and identify the templating molecules or the metabolic pathways involved. This will be useful to better interpret the massive data generated by the increasing use of omics approaches such as metagenomics, metatranscriptomics, metaproteomics to study biomineralizing microbial ecosystems, such as carbonate microbialites $[8,44]$ or calcifying soil microbes [45]. These approaches may provide information about the carbonatogenesis potential of an ecosystem provided if molecular mechanisms favoring or inhibiting biomineralization are sufficiently understood. Here, we review some of our current knowledge about the diversity of bacterial carbonate biomineralization processes and the underlying molecular mechanisms (Fig. 1). We also highlight gaps that will need to be filled to better use omics data in the future. Finally, we shed light on intracellular carbonate biomineralization that is often overlooked although current studies suggest that it is more widespread than previously thought.

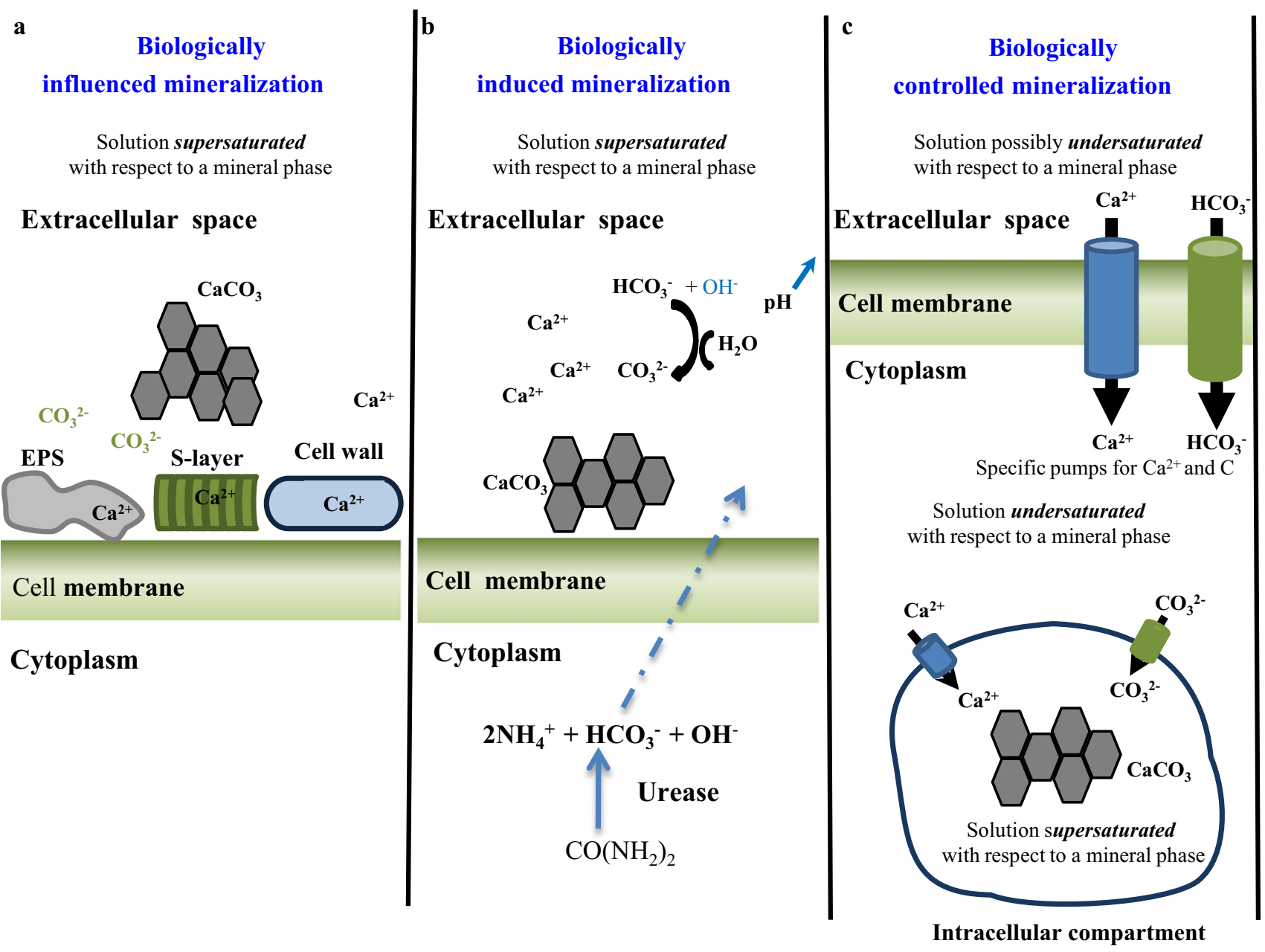

Fig. 1 Classification of the $\mathrm{CaCO}_{3}$ biomineralization processes found in bacteria: a biologically influenced mineralization; $\mathbf{b}$ biologically induced mineralization; c biologically controlled mineralization. The grey hexagons represent $\mathrm{CaCO}_{3}$ precipitates. $\mathrm{Ca}^{2+}$ cations can be replaced by, e.g. other alkaline earth elements such as $\mathrm{Mg}^{2+}, \mathrm{Sr}^{2+}, \mathrm{Ba}^{2+}$ 


\section{Main text}

\subsection{Bacterially influenced mineralization of calcium carbonates}

This mode of mineralization has been sometimes named organomineralization by Trichet and Défarge [46]. A broad diversity of molecules, mostly (glyco-)proteins and polysaccharides, has been shown to impact the nucleation of carbonates in eukaryotes and metazoans [47]. However, they are less documented in bacteria. There are distinct supporting theories behind that: first, it has been suggested that a continuum exists between biomineralization and cation adsorption by diverse functional groups at the bacterial surfaces/exopolysaccharides [48]. In this respect, the local adsorption of cations such as $\mathrm{Ca}^{2+}$ or $\mathrm{Mg}^{2+}$ may drive the subsequent nucleation. Alternatively, it has been convincingly shown that diverse organic molecules, including polysaccharides, favor nucleation by decreasing the net interfacial energy between the growing crystal, the substrate and the solution [40] (see Additional file 1).

\subsubsection{Influence of extracellular polymeric substances (EPS)}

EPS are a complex mixture of high-molecular-weight polymers, mostly composed of polysaccharides with some nucleic acids, lipids, proteins, and other polymers such as humic acids [49]. EPS are a major component of biofilms, sometimes accounting for more than $90 \%$ of their dry mass [49], and support the aggregation of cells and attachment to surfaces [50]. Polysaccharides have been repeatedly observed as intimately and pervasively associated with carbonate mineral grains suggesting their involvement in mineral precipitation, possibly through mineral templating [51, 52] (Fig. 2). The

Fig. 2 Some diversity of the molecules involved in biologically influenced mineralization of $\mathrm{CaCO}_{3}$ : a extracellular polymeric substances, comprising polysaccharides and proteins; b surface layers; c cell walls comprising teichoic and/ or dipicolinic acid functions and/or proteoglycans and glycoproteins a

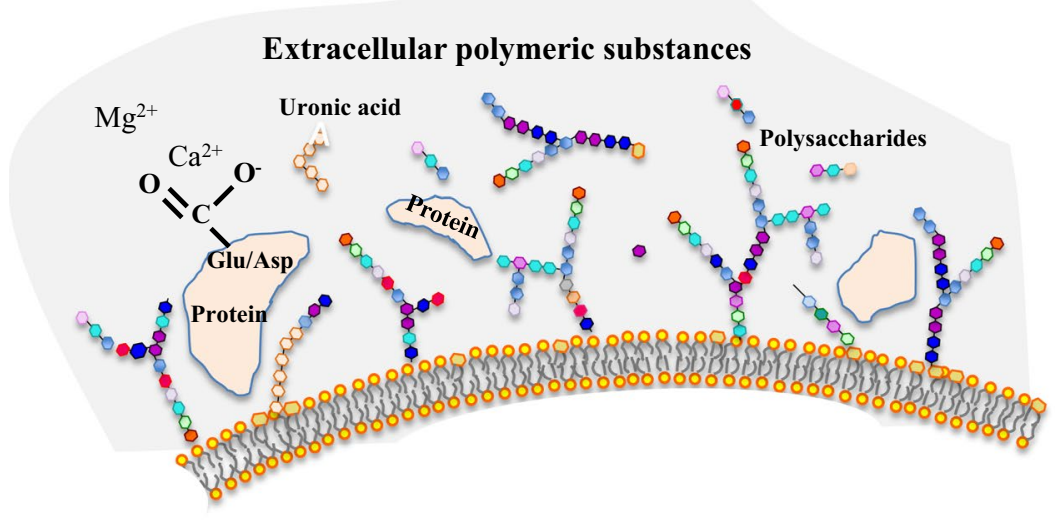

b

c

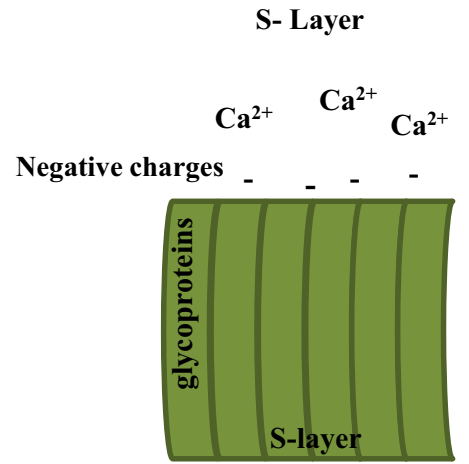

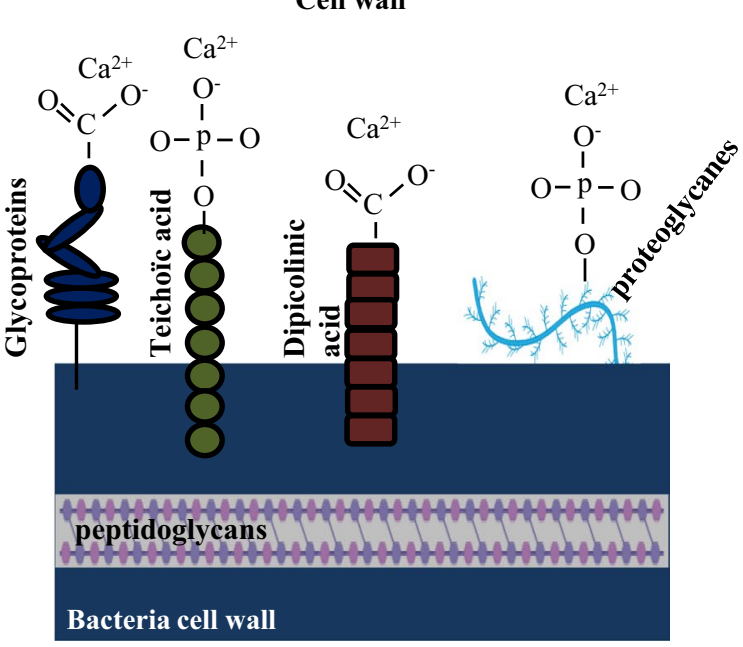


diversity of bacteria capable of producing EPS is tremendous, including Cyanobacteria, sulfate-reducing bacteria and other diverse Proteobacteria [53]. By studying functional genes in lacustrine carbonate microbialites, Saghaï et al. [8] showed that genes associated with trehalose and rhamnose synthesis were mostly affiliated to Cyanobacteria, Alphaproteobacteria and Gammaproteobacteria. Genes involved in the metabolism of other sugars were dominated by some of these phyla and additional ones. Bacteria produce hundreds of different EPS with various chemical structures [54]. This chemical and structural diversity of EPS relies on the identity and number of the saccharide monomers, the glycosidic linkages and the nature of functional groups. There is also a broad diversity of bacteria able to degrade EPS that can be found in carbonatogenic environments [55]. Overall, how the chemical diversity of EPS matters for the precipitation of carbonate mineral phases needs to be better assessed. In the future, this may help assessing which bacterial groups may have more impact on carbonatogenesis based on their EPS production.

There are still diverging views about how EPS are involved in carbonate precipitation. In some cases, it has been proposed that acidic polysaccharides inhibit carbonate precipitation [56, 57]. As a result, carbonatogenesis may occur in EPS-poor areas only, where high concentrations of $\mathrm{Ca}^{2+}$ and $\mathrm{Mg}^{2+}$ have been released by the degradation of polysaccharides by heterotrophic bacteria [58]. Alternatively, it has been speculated that EPS may transform upon decay into a highly organized template structure favoring calcium carbonate nucleation [46].

Giuffre et al. [40] provided a different-yet compatible-view based on a more mechanistically-proven basis. They showed that charge density is a prominent parameter to predict the impact of EPS on nucleation: the higher the charge density (e.g. presence of highly sulfated or carboxylated polysaccharides), the greater the energy barrier for nucleation. As a result, EPS with higher charge density induce higher nucleation rates at higher supersaturation indices of the solution, while at lower supersaturation indices, near-neutral EPS macromolecules induce higher nucleation rates. Structural variations in EPS impact nucleation rates to a lower extent than charge densities.

Moreover, the EPS composition with respect to uronic acid, carbohydrates and protein influence carbonate polymorphism in vitro [57], with some EPS favoring aragonite precipitation, while others favor calcite formation (Fig. 2). This might be particularly related to the identity of some small acidic proteins. These proteins, more precisely their aspartic acid residue (Asp) possibly interact with the surface of the growing precursor crystals and inhibit further transformation into the most stable polymorph, i.e., most often calcite [59]. Similarly, variations of xanthan content and the presence of acidic amino-acids were shown to impact carbonate phase polymorphism and crystal habits [60]. Consistently, Han et al. [10] recently showed that EPS produced by Bacillus subtilis species [10] (see Additional file 1) contain abundant acidic aminoacids such as glutamic acid and Asp, and act as nucleation sites for carbonate mineral phases in supersaturated solutions. Lastly, high molecular weight acidic proteins secreted by some bacteria were shown to influence the precipitation of diverse mineral phases including carbonates [61]. The significance of such secretions remains to be more widely assessed.

Systematically exploring the relationship between chemical and structural properties of EPS and nucleation rates as well as crystal habits and carbonate polymorphism will be an important achievement. This might depend on the chemical conditions prevailing where carbonatogenesis occurs [40]. Among the different approaches to test relationships between EPS and carbonate formation, it will be very interesting to use EPS-producing and EPS-free mutants of cyanobacterial strains [62]. Finally, dedicated metagenome analyses may also help to better assess the relationship between taxonomic diversity and EPS that may have a strong impact on carbonatogenesis.

\subsubsection{Influence of bacterial cell walls}

The cell walls of Myxococcus xanthus were shown to favor the precipitation of calcite and phosphate mineral phases in supersaturated solutions $[63,64]$. Negatively charged functional groups in glycoproteins and proteoglycans (Fig. 2) play a role in heterogeneous nucleation but the need for some stereochemical analogy between the calcite surface and nucleating polymers has also been briefly suggested. Independently, calcite precipitation by Myxococcus xanthus can also be triggered in some cases by the supersaturation increase caused by the cell metabolic activity as further explained below [63]. The cell wall of Bacillus subtilis, mostly composed of peptidoglycan and teichoic acids was also shown to promote the nucleation of carbonate mineral phases. This occurred even when cells were dead or disrupted, demonstrating a clear case of biologically-influenced mineralization [65]. The exact molecular drivers were not identified but nucleating properties were kept even when the cell wall fraction was heated up to $100^{\circ} \mathrm{C}$.

Several studies have characterized the functional groups composing biomolecules at the surface of bacteria, regardless of the nature of the biomolecules $[66,67]$. They have quantified their surface densities and acidity constants to model their capabilities to adsorb cations [66]. In particular, they have tracked functional groups, which are negatively charged at alkaline $\mathrm{pH}$ and can therefore interact with $\mathrm{Ca}^{2+}$. These functional groups, carried by cell bound polysaccharides but 
not exclusively, are involved in passive nucleation of $\mathrm{CaCO}_{3}$ by bacteria [68]. Carboxylate and phosphoryl functional groups likely play the major role [69-71]. In contrast, Martinez et al. [72] suggested that some bacteria may express different functional groups at their surface such as amines, creating a positively charged surface which impedes carbonate precipitation. The precise biochemical carriers of these amine groups remain uncertain.

Surface layers (S-layers), a single layer of identical (glyco-)proteins arranged periodically and integrated within the cell walls of some bacteria, have received attention for their role in the precipitation of $\mathrm{CaCO}_{3}$ phases by the Synechococcus strain GL24 [73] (Fig. 2). Mineral nucleation starts on negatively charged binding sites, which are located at a high density within the large holes of the S-layer arrays [74]. Moreover, the mineralized S-layer can be shed by the cells, feeding carbonate deposition in lakes [73]. Despite the importance of these pioneering studies, none to our knowledge has further assessed the significance of these proteinaceous structures in bacterial carbonatogenesis.

More recently, Marvasi et al. [75] evidenced the role in carbonatogenesis of two additional types of organic molecules abundantly found in some bacterial cell walls: dipicolinic acid (DPA, pyridine-2,6-dicarboxylic acid), a pyridine ring substituted by two carboxylic functional groups, and teichoic acids, polymers of glycerol- or ribitol-phosphate and carbohydrates linked by phosphodiester bonds (Fig. 2). This was achieved by the production of B. subtilis etfA deletion mutants impaired in their capability to precipitate $\mathrm{CaCO}_{3}$, which possess significantly less dipicolinic acid and teichoic acid in their cell walls. Interestingly, DPA was also previously shown to be involved in very high Ca accumulation by $B$. subtilis endospores [76].

In this section, we focused on influenced mineralization mode. It is mediated by a diversity of molecules favoring heterogeneous nucleation, which operate even in metabolically inactive cells, as long as the extracellular solution is supersaturated with mineral precipitates. In the case of metabolically active cells, their impact can combine with a local increase of the solution supersaturation induced by some metabolic reactions that we discuss below, and which contribute to biologically induced mineralization [77].

\subsubsection{Bacterially induced mineralization of calcium carbonates}

This section focuses on bacterial metabolic activities promoting and/or speeding up the kinetics of carbonate precipitation by shifting extracellular chemical conditions.

Calcium carbonate precipitation is a chemical reaction that can be captured by the following equation:

$$
\mathrm{Ca}^{2+}+\mathrm{CO}_{3}^{2-}=\mathrm{CaCO}_{3}\left(\mathrm{~K}_{\mathrm{s}}\right)
$$

where $\mathrm{K}_{\mathrm{s}}$ is the solubility constant which depends on the structure of the $\mathrm{CaCO}_{3}$ mineral phase and temperature. The activity product of the reactants, $\mathrm{Q}$, is defined as: $\mathrm{Q}=\mathrm{a}\left(\mathrm{Ca}^{2+}\right) \cdot \mathrm{a}\left(\mathrm{CO}_{3}^{2-}\right)$, where $\mathrm{a}()$ refers to the activity of chemical species.

When $\mathrm{Q}$ exceeds the $\mathrm{K}_{\mathrm{s}}$ of a mineral phase, the solution is supersaturated with this phase and precipitation may thermodynamically occur. $\mathrm{Q}$ depends on the concentrations of $\mathrm{Ca}^{2+}$ and $\mathrm{CO}_{3}^{2-}$, hence on the concentrations of $\mathrm{Ca}^{2+}$ and $\mathrm{HCO}_{3}^{-}$, and $\mathrm{pH}$. By modifying $\mathrm{pH}, \mathrm{a}\left(\mathrm{Ca}^{2+}\right)$ and/or $\mathrm{a}\left(\mathrm{HCO}_{3}^{-}\right)$, at least locally, a metabolizing bacterium can increase the saturation of a solution to a value exceeding mineral solubility, thereby rendering precipitation thermodynamically possible when it was not possible before the bacterial action. In many cases, organisms thrive in solutions, which are already saturated/ supersaturated with some mineral phases. However, in slightly supersaturated solutions, precipitation may be slow [78]. Morse et al. [79] suggest that $Q$ should be 20-30 times higher than $\mathrm{K}_{\mathrm{s}}$ so that carbonate mineral phases precipitate spontaneously, i.e. within a few hours to a day. Under these circumstances, the increase of the solution saturation by biological activity speeds up the kinetics of precipitation and makes it effectively occurring [80].

The increase of $\mathrm{a}\left(\mathrm{CO}_{3}^{2-}\right)$ induced by metabolic activities has been called the intrinsic'alkalinity engine' [41]. The diversity of metabolic pathways contributing to this has been particularly studied in the context of microbialites. Alternatively, some bacterial processes may increase at least locally $\mathrm{a}\left(\mathrm{Ca}^{2+}\right)$, contributing overall to the increase of $\mathrm{Q}$ as well.

\subsubsection{The diversity of metabolic pathways involved in the alkaline engine}

As mentioned above, any metabolic pathway increasing $\mathrm{a}\left(\mathrm{CO}_{3}^{2-}\right)$, i.e. increasing $\left[\mathrm{HCO}_{3}^{-}\right]$at a constant $\mathrm{pH}$ and/or increasing $\mathrm{pH}$ at a constant $\left[\mathrm{HCO}_{3}^{-}\right]$, favors the precipitation of carbonate mineral phases. An increasing number of studies assessing microbial diversity in microbialites aim at highlighting these metabolic pathways [55, 81]. 
2.1.4.1 Photo- and chemo-autotrophy In the context of microbialites, photolithoautotrophs and in particular cyanobacteria have received thorough attention for their involvement in carbonate biomineralization. Indeed, many cyanobacteria tend to increase the $\mathrm{pH}$ of extracellular solutions that are not highly $\mathrm{pH}$-buffered. Overall, this is due to their propensity to fix $\mathrm{CO}_{2}$ using RuBisCO after bicarbonate ions $\left(\mathrm{HCO}_{3}^{-}\right)$uptake. Indeed, this results in a net consumption of protons by the cells, hence an increase of extracellular $\mathrm{pH}$ [82]. There may be no net proton consumption by cyanobacteria and therefore no impact on carbonatogenesis, in environments where enough $\mathrm{CO}_{2}$ is available because $\mathrm{CO}_{2}$ might be preferentially used over $\mathrm{HCO}_{3}^{-}$. However, while high environmental $\mathrm{pCO}_{2}$ may have been common on the Precambrian Earth $[20,83]$, this is usually not the case in most modern aqueous environments. In that case, inorganic carbon acquisition mostly involves the active uptake of $\mathrm{HCO}_{3}^{-}$. A complex set of molecular pathways increases $\mathrm{HCO}_{3}^{-}$uptake, storage and conversion to $\mathrm{CO}_{2}$ within the cells. Altogether, these pathways are referred to as $\mathrm{CO}_{2}$-concentrating mechanisms (CCM) (Fig. 3). There is a broad diversity of molecular actors involved in CCM among the diverse lineages of cyanobacteria [84, 85]. More specifically, $\mathrm{HCO}_{3}^{-}$ions are imported against their concentration gradient by a diversity of transporters, such as through a symport with $\mathrm{Na}^{2+}$ or by ATP hydrolysis [85]. The expression of some of these transporters-encoding genes is constitutive, while it is induced for some others when $\mathrm{CO}_{2}$ fugacity is low enough. This shows that CCM can partly respond to environmental conditions and that inferring the genetic capabilities of strains might not be enough to predict their role in carbonatogenesis.

Bicarbonate is transformed into $\mathrm{CO}_{2}$ by carbonic anhydrases (CAs) within microcompartments delimited by protein shell, called carboxysomes. This releases hydroxyl ions, which are buffered by the import of $\mathrm{H}^{+}$for the sake of intracellular $\mathrm{pH}$ regulation. As a result, extracellular $\mathrm{pH}$ and therefore the extracellular solution saturation increase with regard to carbonate mineral phases [20]. Moreover, it has been suggested that part of the $\mathrm{H}^{+}$import can be achieved by antiport with $\mathrm{Ca}^{2+}$ ions by $\mathrm{Ca}^{2+} / \mathrm{H}^{+}$exchangers. This further increases extracellular solution saturation with calcium carbonate mineral phases [86]. A link between a $\mathrm{Ca}^{2+} / \mathrm{H}^{+}$exchanger and an $\mathrm{HCO}_{3}^{-}$transporter has been shown in Synechocystis PCC 6803. Indeed, the inactivation of the single $\mathrm{Ca}^{2+/} \mathrm{H}^{+}$exchanger (slr1336) found in this organism significantly increased the calcification rate and stimulated the expression levels of CCM-related genes, especially $\mathrm{cmpA}$, which encodes the $\mathrm{BCT} 1 \mathrm{HCO}_{3}^{-}$transporter [87].

Carbonic anhydrases are $\mathrm{Zn}(\mathrm{II})$-(and/or Fe(II)- or $\mathrm{Co}(\mathrm{II})$-) metalloenzymes catalyzing the reversible hydration of $\mathrm{CO}_{2}$, i.e. the interconversion of $\mathrm{CO}_{2}$ and $\mathrm{HCO}_{3}^{-}$. Therefore, they participate in $\mathrm{pH}$ regulation, and inorganic carbon handling. They have been intensively studied in the context of $\mathrm{CO}_{2}$ capture and sequestration [88, 89]. While they have been shown to be major players in eukaryotic calcification [90], their role in bacterial carbonatogenesis often remains neglected [91]. CAs are ubiquitous in the kingdom of Bacteria and diverse, belonging to three families $(a, \beta, \gamma)$, which may have evolved from a $\gamma$-like ancestral CA [92-94]. A broad structural diversity occurs amongst CAs, which can exist as monomers or

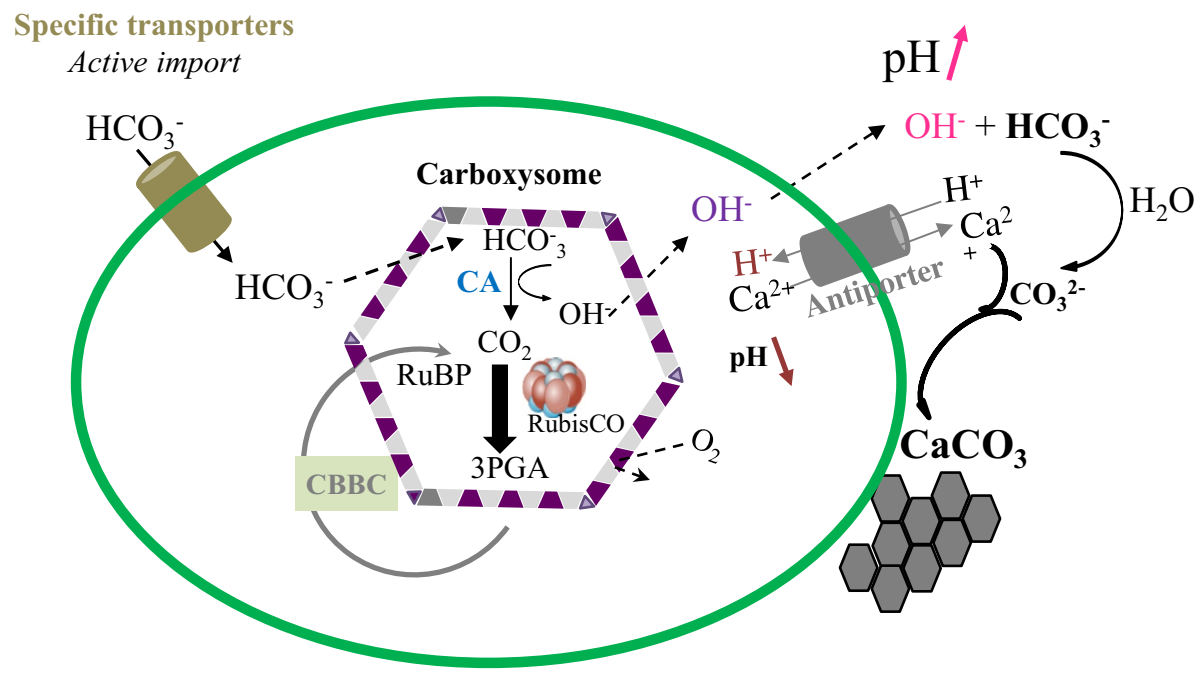

Fig. 3 Simplified model of CCM-dependent biologically induced mineralization of $\mathrm{CaCO}_{3}$. Carbon concentrating mechanism $\mathrm{CCM}$ involves the uptake of $\mathrm{HCO}_{3}^{-}$. Carbonic anhydrase $(\mathrm{CA})$ converts $\mathrm{CO}_{2}$ into $\mathrm{HCO}_{3}^{-}$in the cytoplasm and $\mathrm{HCO}_{3}^{-}$into $\mathrm{CO}_{2}$ in the carboxysome. $\mathrm{CO}_{2}$ is fixed by Rubis CO and used by the Calvin-Benson-Bassham Cycle (CBBC). Conversion of $\mathrm{HCO}_{3}^{-}$into $\mathrm{CO}_{2}$ releases $\mathrm{OH}^{-}$. To buffer intracellular $\mathrm{pH}$, specific transporters such as $\mathrm{Ca}^{2+} / \mathrm{H}^{+}$antiporters import $\mathrm{H}^{+}$and export $\mathrm{Ca}^{2+}$. The import of $\mathrm{H}^{+}$inside the cell lead to an increase of the extracellular $\mathrm{pH}$, which together with export of $\mathrm{Ca}^{2+}$ favors the precipitation of extracellular $\mathrm{CaCO}_{3}[20,30,172]$ 
polymers, coupled with a low sequence similarity [94]. Cell localization is also diverse, some CAs being intracellular, intra-organellar and others periplasmic or extracellular [93]. How this localization may control their capability to induce carbonatogenesis remains to be determined.

A recombinant $\gamma$-carbonic anhydrase from Serratia sp. expressed and purified in $E$. coli was capable to promote the precipitation of calcite. Its activity was optimal at near-neutral $\mathrm{pH}(7.6-8.0)$ at $4{ }^{\circ} \mathrm{C}$ [95]. Moreover, some CAs were shown to be more efficient than others at inducing $\mathrm{CaCO}_{3}$ precipitation $[37,96]$. Overall, targeting $\mathrm{CAs}$ seems important to decipher the carbonatogenic capabilities of a strain but further work is needed to understand what controls the carbonatogenic efficiency of CAs and if some specific CAs families should be more particularly targeted.

However, many uncertainties remain about the prime molecular mechanisms involved in carbonatogenesis by autotrophs and the way to predict their carbonatogenic capabilities. First, are there cyanobacteria harboring particularly effective CCMs that may therefore strongly impact carbonatogenesis? Second, which part of intracellular pH regulation is achieved by the functioning of $\mathrm{Ca}^{2+} / \mathrm{H}^{+}$exchangers $v$ s other $\mathrm{H}^{+}$transporters in calcifying cyanobacteria? Third, there is still some debate about the way cyanobacteria impact carbonatogenesis: do they induce carbonatogenesis through their metabolic activity as stressed on in the above lines [97, 98], or do they influence it through inactive heterogeneous nucleation (e.g. biologically influenced mineralization, see above). In the latter case, molecules at cell surface would play a dominant role [68]. One possible explanation for the conflicting conclusions of these studies is that experiments maintaining relatively high $\mathrm{pCO}_{2}$ conditions [68] may undermine CCM effects and therefore favor heterogeneous nucleation over biologically induced mineralization. Last but not least, it should be noted that some endolithic cyanobacteria, despite having the same molecular apparatus as described above, are known to induce $\mathrm{CaCO}_{3}$ dissolution instead of precipitation [99]. Deciphering the molecular reasons that make a cell dissolve or precipitate $\mathrm{CaCO}_{3}$ will be crucial in the future. In that regard, Zhu et al. [100] showed that the non-photosynthetic bacterium Brevibacterium linens BS258 can induce precipitation or dissolution of $\mathrm{CaCO}_{3}$ depending on extracellular $\mathrm{Ca}^{2+}$ concentration and the subsequent variations in CA genes expression.

Finally, the relationship between the metabolic activity of cyanobacteria and the induction of carbonate mineral phase precipitation may be generalized to all other bacteria using the $\mathrm{CO}_{2}$-assimilating Calvin-Benson-Bassham cycle and also to all other autotrophic carbon fixation pathways such as the reductive citric acid cycle, the Wood-Ljungdahl pathway, and the dicarboxylate/4-hydroxybutyrate cycle [101], at least when cells both incorporate bicarbonate and fix $\mathrm{CO}_{2}$. Although some studies have stressed on the role of anoxygenic phototrophs in carbonate precipitation, e.g. in microbialites $[8,102]$, the assessment of the contribution of this much broader bacterial (and archaeal) diversity to carbonatogenesis and how CCM might be widespread and effective in them remain poorly explored.

\subsubsection{Other carbon-based metabolic pathways}

2.1.5.1 Methanotrophy Anaerobic methane oxidation has been shown as a pathway inducing the precipitation of significant amounts of carbonate mineral phases with low $\delta^{13} \mathrm{C}$ [103]. In contrast, aerobic methane oxidation should favor carbonate dissolution since it releases $\mathrm{CO}_{2}$ [104]. However, some studies have shown that the so-generated $\mathrm{CO}_{2}$ with low

$\delta^{13} \mathrm{C}$ may be re-sequestered within $\mathrm{Mn}$ - and/or Fe-rich carbonates under particular conditions [105]. Anaerobic-methane oxidation can be coupled by some Bacteria and/or Archaea with the reduction of sulfates (in consortia associating Archaea and Bacteria), nitrates, nitrites, humic acids, iron or manganese [106]. Bacterial methanotrophs can be detected based on genes coding for the particulate $(p m o A)$ or soluble $(m m o X)$ forms of the methane monooxygenase [106], while Archaeal methanotrophs can be detected by the presence of the $m c r A$ gene encoding methyl co-enzyme reductase.

2.1.5.2 Fatty acid catabolism Three mechanisms are proposed to mediate bacterially-induced carbonate mineralization in B. subtilis. One occurs through ureolysis (see below), whereas the other two take place in urea-free growth media through the production of dipicolinic and teichoic acids (see above) or in connection with the fatty acid metabolism $[107,108]$. Several mutants impaired in their ability to precipitate calcite in urea-deprived growth media highlighted the involvement of several operons including yus, yko and eft genes [107]. The IcfA operon composed of five genes (IcfA, $f a d R, f a d B$, etfB, and etfA) received particular attention. etfA encodes a putative flavoprotein possibly involved in the metabolism of fatty acids, which appeared to be essential for calcite precipitation in the absence of urea [108]. It was suggested that the loss of calcite precipitation in the eftA mutants was due to a higher extracellular release of $\mathrm{H}^{+}$no longer consumed by the fatty acids metabolism as compared to the wild-type strain, which favors extracellular $\mathrm{CaCO}_{3}$ precipitation [109]. In a later study, Marvasi et al. [68] suggested that the eftA mutation may also change the phospholip- 
ids membrane composition, which therefore may have a role in calcite precipitation. Overall, it becomes apparent that $B$. subtilis can induce $\mathrm{CaCO}_{3}$ precipitation through various mechanisms depending on the culture conditions.

2.1.5.3 Ureolysis Bacterial ureolysis has also received particular attention, especially from studies with applied purposes since it seems capable of inducing massive carbonate precipitation [37, 110, 111]. The hydrolysis of urea $\left(\mathrm{CO}\left(\mathrm{NH}_{2}\right)_{2}\right)$ releases ammonium $\left(\mathrm{NH}_{4}^{+}\right), \mathrm{HCO}_{3}^{-}$and hydroxyls, the two latter contributing to the high increase of solution saturation with carbonate phases, hence their precipitation. Ureolysis primarily depends on the activity of the urease with some additional role of cell surfaces in the heterogeneous nucleation of the mineral phases [112]. Consistently, strong carbonatogenesis capabilities could be conferred to the E. coli HB101 strain harboring a plasmid encoding Bacillus pasteurii (Sporosarcina pasteurii) urease genes [113]. Similarly, mutants of S. pasteurii with urease activities higher than the wild type strain produced more calcite [114].

Ureases can be found in a wide diversity of organisms, including a broad diversity of bacteria [112, 115]. Almost all ureases are cytoplasmic and can constitute up to $1 \%$ of the cell dry weight in S. pasteurii [113]. However, ureases can also catalyze ureolysis extracellularly, and it has been reported that soil matrix-bound ureases can represent significant players of ureolysis [116].

Bacterial ureases are high molecular weight, cysteine-rich enzymes belonging to the superfamily of amidohydrolases and phosphotriesterases [117]. Genes coding for the three subunits (ureA, ure $B$ and ure $C$ ) as well as accessory proteins (UreF, UreH, and UreG, involved in the nickel active site assembly) can be tracked in genomes [100, 110]. Moreover, the ure $\mathrm{C}$ gene, encoding the well-conserved subunit harboring the nickel catalytic active site has been used as a marker gene that can be tracked by molecular approaches [115].

Some structural diversity among bacterial ureases may be associated with variations in affinities for substrates [112] and $\mathrm{pH}$ of optimal activity [117].

Carbonate precipitation by ureolytic bacteria follows a Michaelis-Menten kinetics with ureolysis as the rate-limiting step [118]. Carbonatogenesis rates are therefore organism-dependent since they depend on the activity of the intrinsic urease [119]. Moreover, when ureolysis occurs intracellularly, the efficiency of cell transmembrane transport of urea by urea permeases, of ammonia, protons and $\mathrm{Ni}$ by transporter systems matter for the overall carbonatogenesis capabilities of the cells [113]. Finally, it has been suggested that synergies exist between the functioning of ureases and CAs in addition to their direct contribution to calcification, since, e.g. Ni incorporation in urease is dependent on the intracellular $\mathrm{CO}_{2} / \mathrm{HCO}_{3}^{-}$ratio, which is regulated by $\mathrm{CA}$ [91].

Ureolysis activity can also be affected by external environmental conditions, including $\mathrm{pH}$ [111], urea concentration and temperature [118]. For example, a pH increase can favor in some soils the growth of urease-producing microorganisms, resulting in an increased number of ure C detected copies and an increased ureolysis rate [120]. In contrast, oxygen fugacity does not have a direct impact on urease activity, but anoxic conditions may impede the growth of aerobic strains, therefore urease production, hence carbonatogenic activity [118]. Some authors have suggested that the activity of urease can be modulated by calcium concentration [112]. Zhu et al. [100] showed in the marine Actinobacterium Brevibacterium linens BS258 that an increase of $\mathrm{Ca}^{2+}$ upregulated the expression of genes encoding peptide/nickel $A B C$ transporters which boosted urease activity. Whether this correlation is systematically positive is yet to clarify.

Ureolytic bacteria are found in a wide range of environments [115]. Interestingly, it has been suggested that ureolysis may play a role in the formation of some microbialites, based on the metagenomics detection of urea $A B C$ transporters, and ureases, dominated by genes of Proteobacteria [81].

2.1.5.4 Other nitrogen-related metabolic pathways Nitrate reduction and ammonification of amino-acids are prone to induce the precipitation of $\mathrm{CaCO}_{3}[121,122]$. Some of these processes are dissimilatory, i.e. reduction provides ATP to the cell, while others are assimilatory, i.e., they serve as a source of nitrogen for biosynthesis. Interestingly, nitrate reduction has been highlighted by Drew [123] as an important mechanism in marine carbonate precipitation already a century ago, but its significance in modern $\mathrm{CaCO}_{3}$ precipitation remains poorly assessed.

Denitrification consists in the reduction of $\mathrm{NO}_{3}^{-}$(nitrate) to $\mathrm{N}_{2}$ through several intermediates, including nitrite $\left(\mathrm{NO}_{2}^{-}\right)$, nitric oxide (NO), and nitrous oxide $\left(\mathrm{N}_{2} \mathrm{O}\right)$. Each step of denitrification is catalyzed by various enzymes harboring diverse metal cofactors. The first one is performed by either periplasmic or cytoplasmic nitrate reductases, encoded by nap $A B$ and narGHI genes, respectively [124-126]. Overall, more than 50 genes in a genome are encoding the core structures of the denitrification apparatus [124]. Nitrate reduction encompasses a larger group of bacteria, some of which proceeding through the first $\mathrm{NO}_{3}^{-} \rightarrow \mathrm{NO}_{2}^{-}$step only. 
Nitrate is used as an electron acceptor in anoxic environments by bacteria that are often facultative nitrate reducers. Nitrate reduction can be coupled by diverse heterotrophic bacteria with the oxidation of organic $\mathrm{C}$ but also by some autotrophic bacteria with alternative electron donors including $\mathrm{H}_{2}$ and reduced $\mathrm{S}$, As and Fe chemical species [127]. Depending on the electron donor, nitrate reduction consumes (e.g. organic $\mathrm{C}, \mathrm{H}_{2}, \mathrm{HS}^{-}$), or produces (e.g. $\mathrm{S}_{2} \mathrm{O}_{3}^{2-}, \mathrm{Fe}^{2+}$, $\mathrm{Mn}^{2+}$ ) protons, the former favoring the induction of $\mathrm{CaCO}_{3}$ precipitation. In the case of heterotrophic denitrification, the additional production of $\mathrm{CO}_{2}$ may further impact saturation with $\mathrm{CaCO}_{3}$. For example:

$$
4 \mathrm{NO}_{3}^{-}+5 \mathrm{CH}_{2} \mathrm{O}+4 \mathrm{H}^{+} \rightarrow 2 \mathrm{~N}_{2}+5 \mathrm{CO}_{2}+7 \mathrm{H}_{2} \mathrm{O} \text {. }
$$

Denitrification is distributed among a highly polyphyletic group of bacteria [127]. Therefore, the targeting of functional genes such as narGHI and napAB (encoding the respiratory and periplasmic nitrate reductases respectively) instead of $16 \mathrm{~S}$ rDNA genes has been used to look for nitrate-reducing bacteria in the environment [128].

Nitrate reduction has been studied as a driver of bacterially-induced carbonate precipitation in several geotechnical applications [121] but also in environmental microbial mats where calcification occurs [129]. Although it seems to have a lower efficiency than ureolysis for carbonatogenesis [122], nitrate reduction has been proposed as an alternative pathway for applications where the production of ammonium would be unwanted and/or where wastewater with elevated nitrates concentrations are available [130]. Nitrate reduction may even supplement ureolysis in some cases, and improve $\mathrm{CaCO}_{3}$ precipitation efficiency [130]. High $\mathrm{Ca}^{2+}$ concentrations and urea have been reported to decrease nitrate reduction rates [130], but this effect will need to be assessed more systematically. Heterotrophic denitrification was reported to be optimal at a pH around 7-8 but it can also occur at higher pH [131, 132]. Many other parameters may affect denitrification rates including salinity, limitation of metal cofactors, phosphorus availability [133]. Lastly, Karatas [133] concluded that $\mathrm{CaCO}_{3}$ precipitation is also controlled by the ratio of the alkalinity production (consumption of $\mathrm{H}^{+}$) to $\mathrm{CO}_{2}$ production. This ratio depends on the oxidation state of $\mathrm{C}$ and the $\mathrm{N}$ content in the electron donor. Overall, Pseudomonas aeruginosa and Diaphorobacter nitroreducens are known to promote precipitation via denitrification metabolism [134] (see Additional file 1).

Ammonification refers to diverse processes resulting in the hydrolysis of nitrogenous organic matter and the release of ammonium. This includes the already discussed ureolysis and reduction of nitrate into ammonium. In addition, ammonification of proteins or amino-acids, among others, under oxic conditions was also shown to produce ammonium, sometimes $\mathrm{CO}_{2}$ and to consume $\mathrm{H}^{+}$[135]. Therefore, ammonification is capable of inducing $\mathrm{CaCO}_{3}$ precipitation [37] following the general equation:

$$
\mathrm{R}-\mathrm{NH}_{2}+\mathrm{H}_{3} \mathrm{O}^{+} \rightarrow \mathrm{R}-\mathrm{OH}+\mathrm{NH}_{4}^{+}
$$

It involves multiple steps of protein, peptide and amino acid decomposition by a diversity of enzymes, including proteases, hydratases, peptidases, and deaminases. Reyes et al. [136] provided a list of 47 enzymes retrieved from metagenomes of marine sediments, possibly involved in ammonification. The corresponding genes were among the most abundant genes involved in nitrogen metabolism. Recently, using the model bacterium Alcanivorax borkumensis, Krause et al. [137] proposed that bacterial ammonification might be an important driver of carbonate formation in shallow costal marine environments. Similarly, Rodriguez-Navarro et al. [138] showed the capability of Myxococcus xanthus to induce $\mathrm{CaCO}_{3}$ biomineralization by performing oxidative deamination of amino acids.

2.1.5.5 Sulfur-related metabolic pathways Many studies have highlighted the role of sulfate-reducing bacteria (SRB) in $\mathrm{CaCO}_{3}$ precipitation in anaerobic environment. Braissant et al. [139] enumerated several processes mediated by SRB that favor $\mathrm{CaCO}_{3}$ precipitation: sulfate reduction consumes protons and therefore increases the saturation of the extracellular solution. SRB also increase $\mathrm{Ca}^{2+}$ activity. Indeed, the degradation of $\mathrm{Ca}^{2+}$-complexing carboxylic acids by SRB may locally release $\mathrm{Ca}^{2+}$. Moreover, by removing sulfates ions, they also relieve the kinetic inhibition of dolomite precipitation. Last but not least, the EPS produced by SRB may favor influenced mineralization. However, SRB may alternatively decrease the $\mathrm{pH}$ of the extracellular solution to an extent that depends on the electron donors used, so that the positive impact of SRB on $\mathrm{CaCO}_{3}$ precipitation should not be considered as systematic [140]. Moreover, Aloisi [141] suggested that SRB may have a limited impact on the increase of saturation with $\mathrm{CaCO}_{3}$, in comparison with oxygenic photosynthesis. In contrast, SRB have been advocated as important players in the formation of the modern microbialites in the Bahamas [142]. Whether this is due to their metabolic activity or influenced mineralization remains to be clearly assessed.

Sulfide oxidation has sometimes been considered as a metabolism promoting $\mathrm{CaCO}_{3}$ dissolution [41]. This actually depends on the nature of the reactants (sulfides vs. sulfur vs. thiosulfate) and the ultimate byproducts (sulfur vs. 
thiosulfates vs. sulfates). Several sulfoxidizing pathways consume protons and may induce $\mathrm{CaCO}_{3}$ precipitation. Consistently, Himmler et al. [143] proposed that nitrate-driven sulfide oxidation may be involved in the formation of deep stromatolite-like deposits.

\subsection{Biologically induced mineralization by metabolic modifications of extracellular calcium activity}

As already mentioned, the activity of $\mathrm{Ca}^{2+}$ ions also controls the saturation of a solution in respect with $\mathrm{CaCO}_{3}$ phases. Calcium is known to be involved in membrane transport mechanisms, photosynthesis, cell division, cell differentiation processes such as sporulation, and heterocyst formation [144]. The intracellular $\mathrm{Ca}^{2+}$ concentration is tightly regulated at a low value, in the submicromolar range. In the environment, calcium concentration is usually up to $10^{3}$ times higher than intracellular concentration [145]. Therefore, $\mathrm{Ca}^{2+}$ enters into the cell via a passive influx. In contrast, the efflux of $\mathrm{Ca}^{2+}$ is usually active, involving different types of pumps, including ATPases and $\mathrm{Ca}^{2+} / \mathrm{H}^{+}$exchangers. At these locations, the local extrusion of $\mathrm{Ca}^{2+}$ may favor $\mathrm{CaCO}_{3}$ precipitation by an increase of $\mathrm{Ca}^{2+}$ activity, sometimes coupled with a decrease of $\mathrm{H}^{+}$activity [146]. Castanier et al. [33] and McConnaughey and Whelan [147] consistently proposed that $\mathrm{Ca}^{2+}$ extrusion might induce $\mathrm{CaCO}_{3}$ precipitation. Partly supporting this hypothesis, Banks [148] showed that the knock-out mutant of the chaA gene encoding the $\mathrm{Ca}^{2+} / 2 \mathrm{H}^{+}$antiporter of Salmonella typhimurium has lost its capacity to grow on media containing calcium and thus they suggested that calcification might be involved in Ca detoxification. However, the significance of this process in induced (i.e., non-controlled) mineralization remains to explore.

\subsubsection{A particular case of induced $\mathrm{CaCO}_{3}$ mineralization: viral lysis}

$\mathrm{CaCO}_{3}$ precipitation may be induced in some cases by the viral lysis of cyanobacterial cells. This case may not be strictly considered as biologically-induced mineralization since it occurs when cells burst and die. Yet, it involves a local chemical shift created by the cells. A theoretical model was developed based on the following rationale [149]: cyanobacteria use active processes to highly concentrate bicarbonates intracellularly compared to the surrounding solution. Overall, this intracellular dissolved inorganic carbon may represent up to 1 Gigaton in the whole ocean [149]. When the intracellular content is fully released, e.g. by cell rupture following a viral infection, the local increase of bicarbonate concentration in an already supersaturated solution, such as seawater, may be high enough to overcome the energy barrier of homogenous nucleation. As a result, $\mathrm{CaCO}_{3}$ precipitation occurs at once without the involvement of the cell surface. In contrast, homogenous nucleation is kinetically limited in seawater in the absence of viral lysis and never occurs. Only alternative processes such as heterogeneous nucleation on EPS and/or microbial cell surfaces or increase of saturation by metabolic activity would otherwise allow the precipitation of $\mathrm{CaCO}_{3}$. In their model, Lisles and Robbins [149] assessed the outward diffusion of bicarbonate molecules and the inward diffusion of $\mathrm{Ca}^{2+}$ ions after the cell burst and showed that the formation of vaterite became highly favorable in a limited yet significant volume around the cells. They postulated that this process might result in a significant source of carbonate sediments, when it occurs during bloom events with enhanced viral lytic events, possibly in the so-called whiting events. More recently, Xu et al. [150] conducted laboratory experiments to test this model. Consistently, they observed that cyanobacterial cells of Synechococcus sp. PCC 7177 incubated in seawater induced the precipitation of brucite $\left(\mathrm{Mg}(\mathrm{OH})_{2}\right)$, whereas after phage infection, lysed cells seemed to favor amorphous calcium carbonate (ACC) and aragonite precipitation.

\subsection{Bacterially controlled mineralization of calcium carbonates}

Determining the control of mineralization by bacteria is not straightforward. Indeed, it ultimately requires to characterize specific genes and the involved molecular mechanisms. Therefore, we may ignore some cases of controlled mineralization of $\mathrm{CaCO}_{3}$ even among well-studied model bacteria. Presently, there are two accepted cases of bacterially controlled mineralization of $\mathrm{CaCO}_{3}: \mathrm{CaCO}_{3}$ formation by Achromatium sp. and $\mathrm{ACC}$ formation by several cyanobacteria. These cases have several peculiarities compared with the induced and influenced mineralization pathways: (i) mineralization is intracellular; (ii) it can occur under apparently out-of-equilibrium conditions, i.e. in extracellular solutions undersaturated with $\mathrm{CaCO}_{3}$ mineral phases. This biomineralization results from an energetically costly creation of intracellular supersaturated conditions; (iii) Relatedly, the chemical composition and structure of the resulting biominerals may be different from those expected when considering the chemical conditions prevailing extracellularly. Hence, they may be true markers of biogenicity in these environments. 
The first evidence of controlled biomineralization was found in Achromatium, a genus affiliated to the Gammaproteobacteria. It was described by Schewiakoff as early as 1893 [4]. Presently, all known Achromatium species can form intracellular $\mathrm{CaCO}_{3}$ [151]. They are found at the oxic/anoxic boundary in freshwater, brackish or marine sediments [152, 153]. These giant bacteria with cells measuring up to $100 \mu \mathrm{m}$ in length, contain large $(5-6 \mu \mathrm{m})$ inclusions of intracellular $\mathrm{CaCO}_{3}$, which sometimes occupy most of the cell volume. They also contain small $(0.5-2 \mu \mathrm{m})$ sulfur $\left(\mathrm{S}^{0}\right)$ inclusions [153]. Some Achromatium cells were observed to contain intracellular $\mathrm{CaCO}_{3}$ granules in extracellular solutions undersaturated with all $\mathrm{CaCO}_{3}$ phases [151].

The underlying molecular mechanisms are difficult to study because there is no cultivated representative of Achromatium. However, several observations have provided hints. First, some TEM observations have suggested a membrane around $\mathrm{CaCO}_{3}$ inclusions $[151,153]$. However, this feature is not obvious on published pictures. Recently, Schorn et al. [154] intriguingly suggested that $\mathrm{CaCO}_{3}$ granules in Achromatium may actually form within invaginations of the cytoplasmic membrane, i.e. within the periplasm. If true, this would greatly contradict the current model of $\mathrm{CaCO}_{3}$ formation by Achromatium. This clearly shows that significant work remains to be achieved on this system. Then, the usual three ingredients for $\mathrm{CaCO}_{3}$ mineralization, i.e. $\mathrm{Ca}^{2+}$ and $\mathrm{HCO}_{3}^{-}$provision as well as proton consumption, have been assessed. First, the formation of intracellular $\mathrm{CaCO}_{3}$ granules requires a relatively large amount of $\mathrm{Ca}$, although $\mathrm{Ca}$ is usually poorly available within cells. Thus, $\mathrm{CaCO}_{3}$ biomineralization by Achromatium may involve a specific active mechanism for concentrating $\mathrm{Ca}$ from the environment. Moreover, Salman et al. [152] evidenced an intracellular compartment overlooked so far, which may contain high concentrations of free $\mathrm{Ca}^{2+}$ and where $\mathrm{CaCO}_{3}$ precipitation may start. The detection of genes encoding a plasma membrane $\mathrm{Ca}^{2+}$-ATPase (PMCA-like) and a $\mathrm{Na} / \mathrm{H}^{+}-\mathrm{Ca}$ exchanger ( $y r b G$ ), and several genes encoding pyrophosphatases and vacuolar (V)-type ATPases in the draft genomes obtained by single-cell genome sequencing was discussed in that regard [155]. Second, the provision of $\mathrm{HCO}_{3}{ }^{-}$may be achieved in some Achromatium populations by CCM. Carbonic anhydrase encoding genes were detected in Achromatium draft genomes [155]. However, a gene encoding a RuBisCO large subunit $(r b c L)$ was detected in Achromatium populations from Rydal Water but not in those from Hell Kettle [153]. Similarly, some diversity regarding the capability to grow autotrophically was observed among various Achromatium populations: some were able to assimilate carbon from bicarbonate, while others needed organic $\mathrm{C}$ such as acetate [151]. Finally, a correlation has been observed between variations of environmental $\mathrm{O}_{2}$ fugacity and the amount of sulfur and $\mathrm{CaCO}_{3}$ inclusions within the cells. This led Salman et al. [152] and Yang et al. [156] to propose that intracellular $\mathrm{CaCO}_{3}$ accumulates upon oxidation of sulfide to elemental sulfur, a redox process consuming protons and occurring mostly under anoxic conditions. In contrast, $\mathrm{CaCO}_{3}$ dissolves upon oxidation of sulfur to sulfate, a redox process releasing protons and occurring under oxic conditions (Fig. 4). As a result, $\mathrm{CaCO}_{3}$ formation would be directly related with the sulfur metabolism of the bacteria and serve somehow as a $\mathrm{pH}$ buffer. Accordingly, genes involved in oxidation of sulfide to sulfur and sulfur to sulfate were detected in the draft genomes of Achromatium. The increasing number of molecular studies published lately about Achromatium holds great promises for soon unravelling more completely the mechanisms of $\mathrm{CaCO}_{3}$ biomineralization by this bacterium.

For a long time, it has been believed that only Achromatium performs controlled mineralization of $\mathrm{CaCO}_{3}$ among bacteria until the recent discovery of a similar process in some cyanobacteria. This was first discovered in Gloeomargarita lithophora, a deep-branching cyanobacterium isolated from modern carbonate deposits forming in the highly alkaline $(\mathrm{pH} \sim 8.9)$ Lake Alchichica, Mexico [157, 158]. G. lithophora is the closest extant relative of plastids [159]. Cells harbor intracellular amorphous $\mathrm{Ca}-\mathrm{Mg}-\mathrm{Sr}$-Ba-carbonates granules distributed within the whole cell [157]. There are $21 \pm 5$ inclusions per cells on average, occupying $\sim \%$ of the total cell volume and these inclusions measure $270 \pm 44 \mathrm{~nm}$ in diameter. Fifteen additional cultivable cyanobacterial strains were later found to form intracellular ACC (iACC) [43, 160] (see Additional file 2). Some of these strains had been extensively studied before, including by TEM, supporting the idea that they have been overlooked. This suggests that we may still have an incomplete assessment of the diversity of bacteria forming intracellular $\mathrm{CaCO}_{3}$. Cyanobacteria forming iACC are phylogenetically-distant and live in diverse biotopes such as alkaline lakes, hot springs, or soils $[43,161]$. All the members of the Thermosynechococcus elongatus BP-1 clade, shared the ability to form iACC showing that this biomineralization process is heritable, and might be ancient [43]. Moreover, two types of intracellular distributions of the inclusions were observed among the $16 \mathrm{iACC}$-forming strains known so far: iACC granules were scattered throughout the cells in 11 cyanobacteria, whereas they were located at cell poles and septa in five other cyanobacteria [14, 43, 160, 162] (Fig. 5). In the latter group, iACC formation is therefore obviously related with cell division. Overall, this questions whether a single pathway is involved or iACC biomineralization appeared several times by convergence during evolution in cyanobacteria.

Similar to Achromatium, the molecular mechanisms involved in cyanobacterial iACC biomineralization remain poorly known. However, several observations allow discussing hypotheses. First, in cyanobacteria where ACC formation starts 


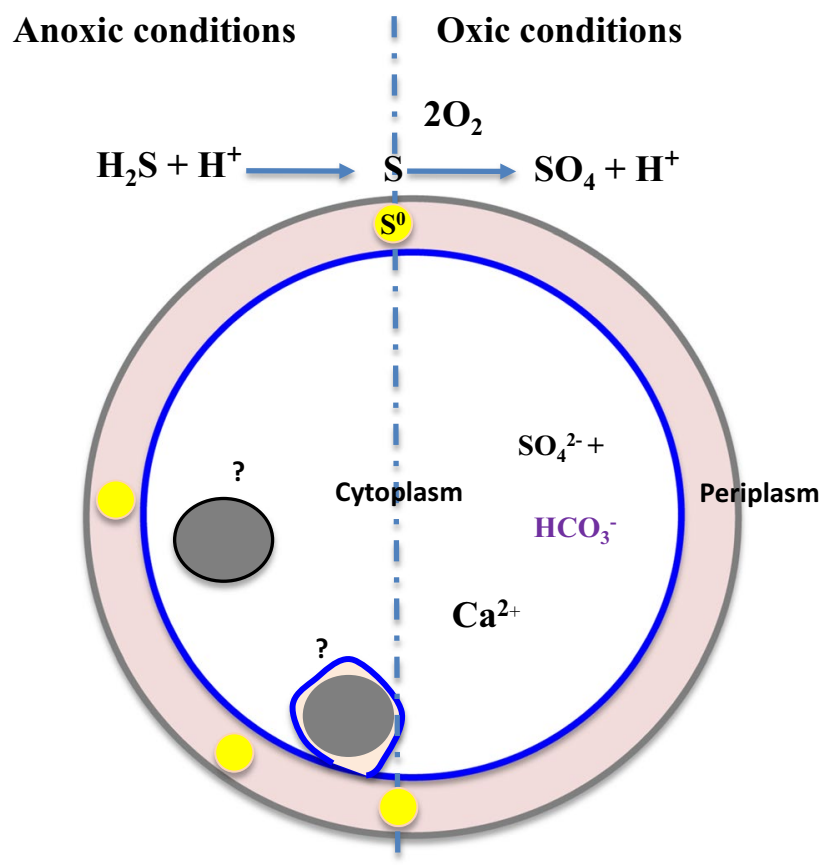

Fig. 4 Intracellular $\mathrm{CaCO}_{3}$ precipitation and the dissolution within Achromatium cells. Protons are consumed when sulfides $\left(\mathrm{H}_{2} \mathrm{~S}\right)$ are oxidized to elemental sulfur under anoxic conditions. This leads to an increase of $\mathrm{pH}$ and precipitation of $\mathrm{CaCO}_{3}$ (grey ellipsoid). Protons are released when elemental sulfur $(\mathrm{S})$ is oxidized to sulfates $\left(\mathrm{SO}_{4}^{2-}\right)$ under oxic conditions. This results in the decrease of $\mathrm{pH}$ and dissolution of $\mathrm{CaCO}_{3}$. Some debate exists about the localization of $\mathrm{CaCO}_{3}$ precipitation: Head et al. [153] and Gray and Head [151] suggested that intracellular $\mathrm{CaCO}_{3}$ are enclosed within an intracellular compartment delimitated by a lipid bilayer (black line). In contrast, Schorn et al. [154] suggested that $\mathrm{CaCO}_{3}$ forms within an invagination of the cytoplasmic membrane (blue line), open to the periplasm
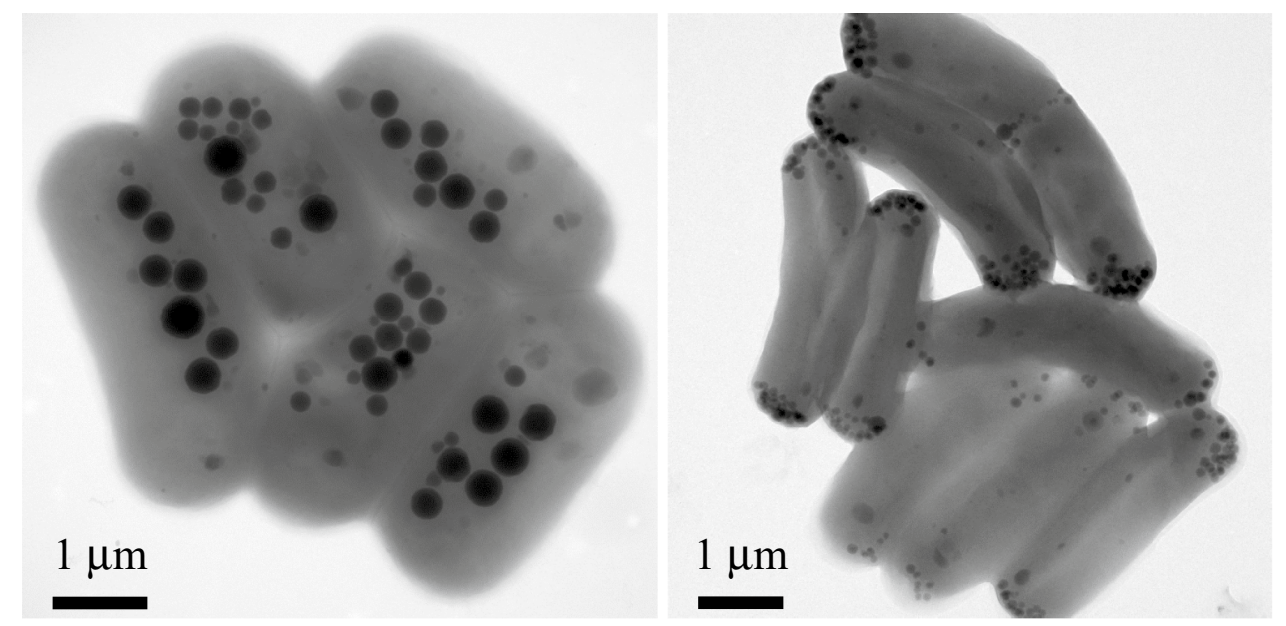

Fig. 5 Transmission electron microscopy images in the bright field mode of ACC-forming cyanobacteria: a Cyanothece sp. PCC 7425 cells showing ACC inclusions (darkest inclusion) scattered throughout the cells; b Synechococcus lividus PCC 6716 cells showing ACC inclusions (darkest inclusions) located at the septum and the poles of the cells [43]. Some brighter inclusions are also visible in both strains and correspond to polyphosphate granules. Identification of polyphosphate and ACC granules was achieved by Benzerara et al. [43] based on STEMEDX mapping, electron diffraction and XANES spectroscopy at the $\mathrm{C} K$-edge and $\mathrm{Ca}_{2,3}$-edges

at the cell septum, the involvement of a $\mathrm{Ca}^{2+}$ influx and nucleation of ACC on the cell division FtsZ protein have been suggested as potential mechanisms [14]. In cyanobacteria where iACC granules were scattered throughout the cells, iACC granules were sometimes aligned and showed facets [14]. Moreover, they showed a tight spatial association with polyphosphate inclusions in G. lithophora, similar to the tight association sometimes observed between polyphosphates and carboxysomes. Overall, based on these observations and since the conversion of bicarbonate ions to $\mathrm{CO}_{2}$ in carboxysomes might be a driver of ACC precipitation, they suggested that ACC precipitation may start on carboxysomes. 
However, this was not confirmed by TEM observations. TEM analyses of samples prepared by conventional ultramicrotomy are not appropriate since iACC dissolves very fast upon sample processing [14]. Blondeau et al. [162] solved the problem by using cryo-electron microscopy of vitreous section (CEMOVIS). As a result, they showed that iACC inclusions were systematically surrounded by an electron dense envelope measuring $\sim 2.5 \mathrm{~nm}$ in thickness, i.e. about half of the thickness of a lipid bilayer. The exact nature of this envelope, either proteinaceous or a lipid monolayer remains unknown. However, this suggests that $\mathrm{ACC}$ forms within an intracellular compartment where $\mathrm{pH}$ and/or $\mathrm{Ca}^{2+}$ and $\mathrm{CO}_{3}^{2-}$ concentrations might be much higher than in the cytoplasm. Moreover, confinement in such a compartment may explain the stabilization of the amorphous structure of $\mathrm{CaCO}_{3}$ [163]. The observation of such a compartment, where chemical conditions might be different from those prevailing in the cytoplasm reconciles our knowledge about the conditions necessary for ACC precipitation and the observation of iACC in cyanobacteria. Indeed, ACC precipitation is thermodynamically impossible under the chemical conditions that are believed to exist within the cytoplasm of cyanobacteria [164]. Similarly, with what has been proposed for Achromatium, an active uptake of $\mathrm{Ca}^{2+}$ may feed iACC biomineralization. This active transport may be at least partly at the origin of the energy cost of this biomineralization pathway and explain how cyanobacteria can form ACC in otherwise undersaturated extracellular solutions [165]. Following the same line of a strong connection between ACC biomineralization and a particular Ca homeostasis, De Wever et al. [160] showed that iACC-forming cyanobacteria incorporate much more $\mathrm{Ca}$ than other cyanobacteria. Moreover, some of the iACC-forming strains require higher Ca concentrations to grow well. However, no molecular actor has been identified yet which might be exclusively shared by all iACC-forming cyanobacteria. Genes coding for $\mathrm{Ca}^{2+} / \mathrm{H}^{+}$exchangers, and diverse calcium/cation exchangers, all involved in Ca active transport, have been found in all studied genomes of iACC-forming cyanobacteria [160]. Genes coding for a mechanosensitive channel have also been found in all these genomes. However, those genes can also be found in bacteria not forming ACC [160]. In contrast, genes coding for $\mathrm{Ca}^{2+}$-ATPases, Pit and $\mathrm{Ca}^{2+} / \mathrm{Na}^{+}$antiporters were found in some but not all iACC-forming cyanobacteria.

Finally, a preferential uptake of the heaviest alkaline earth elements $(\mathrm{Ba}>\mathrm{Sr}>\mathrm{Ca}>\mathrm{Mg}$ ) was observed in $\mathrm{G}$. lithophora but not in several other iACC-forming cyanobacteria, suggesting that it involves additional molecular mechanisms [166]. Such a preferential uptake explains why the $\mathrm{Ba} / \mathrm{Ca}$ and $\mathrm{Sr} / \mathrm{Ca}$ atom ratios of the intracellular carbonates in $\mathrm{G}$. lithophora cells were higher by factors of 1370 and 86 than those prevailing in their extracellular solution. This preferential uptake is interesting since it may have a significant impact on the geochemical cycles of trace alkaline earth elements [167] and may be used to remediate pollutions by radioactive isotopes [15].

As mentioned above, because of the poor stability of ACC and based on recent teachings from the discovery of iACC by cyanobacteria, we may have overlooked a part of the bacterial diversity able to control intracellular biomineralization of $\mathrm{CaCO}_{3}$. Recent field studies have observed non-identified organisms forming intracellular $\mathrm{CaCO}_{3}$ [168]. Exploring further this diversity may help to better understand the molecular mechanisms involved in this biomineralization process.

\section{Conclusions}

A large diversity of mechanisms is involved in the biomineralization of carbonates by bacteria. Biological mediation may involve molecules favoring mineral nucleation by changing the interfacial energy between the extracellular solution and a nascent nucleus (influenced mineralization). Another mode of mediation, compatible with the first one, involves some bacterial metabolic activities. These activities impact the $\mathrm{pH}$ and/or the concentrations of bicarbonate and/or $\mathrm{Ca}^{2+}$ ions of the extracellular solution where cells thrive. Lastly, controlled biomineralization follows similar molecular processes but is distinguished based on the fact that it involves dedicated genes.

In this review, we focused on the diversity of mechanisms involved in bacterial $\mathrm{CaCO}_{3}$ biomineralization. An alternative and yet related question is that of the biological function of this process. The existence of a function in the case of induced and influenced mineralization has been debated. Simkiss [169] proposed that the intracellular precipitation of Ca-rich mineral phases might be a way to detoxify cells from $\mathrm{Ca}$ and contribute to the maintenance of low intracellular $\mathrm{Ca}$ contents. Following this line, Anderson et al. [170] postulated that extracellular formation of $\mathrm{CaCO}_{3}$ might similarly have a role in cell $\mathrm{Ca}$ homeostasis by detoxifying extracellular $\mathrm{Ca}$ excess. The idea that the bacterial mediation of extracellular $\mathrm{CaCO}_{3}$ precipitation may serve the $\mathrm{Ca}$ homeostasis of cells and protect them in Ca-rich environments was repeatedly reaffirmed, including by, e.g. Banks et al. [148]. The way this may be understood is that cells, by lowering the apparent solubility of $\mathrm{CaCO}_{3}$ either by heterogeneous nucleation and/or shifting $\mathrm{pH}$ and/or $\left[\mathrm{HCO}_{3}^{-}\right]$may lower the activity of $\mathrm{Ca}^{2+}$. However, the statement by Simkiss [169] that these precipitates are'highly insoluble deposits' should be put in perspective. $\mathrm{Ca}^{2+}$ activity never becomes null because of the formation of these precipitates but equal to a value imposed by the 
equilibrium between the solution and the precipitated Ca-mineral phase. For example, in the case of iACC biomineralization by cyanobacteria, the expected value of $\mathrm{Ca}^{2+}$ concentration at equilibrium with $\mathrm{ACC}$ when $\mathrm{pH}$ is 7.9 and $\left[\mathrm{HCO}_{3}^{-}\right]$is $30 \mathrm{mM}$ would be $441 \mu \mathrm{M}$, i.e. much higher than the necessary $100 \mathrm{nM}$ regulated by cell homeostasis. This questions the role of these biominerals in this process. Obst et al. [171] did not suggest a real advantage provided to the cells by $\mathrm{CaCO}_{3}$ precipitation but instead postulated that the stabilization of ACC was a protective mechanism against the formation of unwanted crystalline $\mathrm{CaCO}_{3}$. Schultze-Lam et al. [73] proposed that the localization of $\mathrm{CaCO}_{3}$ precipitation on protein $S$-layers that can later on be shed, may serve as a mechanism against cell encrustation. Overall, we note that there may be no function at all for the cell in the case of induced or influenced mineralization. Looking systematically for one function results from an adaptationist (or Panglossian) view. While we acknowledge that selection is a fundamental process, the mineralization of $\mathrm{CaCO}_{3}$ may be a secondary byproduct of other processes, the latter being the ones that are selected for any other reason.

For controlled mineralization, several functions have been suggested: for cyanobacteria it has been proposed that (i) iACC alters the buoyant density of cells and may serve as a ballast [14]; (ii) iACC may serve as a storage of inorganic C for photosynthesis and/or to maintain relatively constant $\mathrm{C} / \mathrm{N}$ ratios within the cells [110]; (iii) alternatively, carbonate precipitation may act as pH buffer during photosynthesis [157]. Similar hypotheses have been formulated for Achromatium, including a role of $\mathrm{pH}$ buffer during redox reactions affecting the different sulfur species. Controlled mineralization of carbonates has often been described in eukaryotes. Only a future detailed understanding of the molecular processes and actors involved in bacterial biomineralization will help to infer whether some of them might be shared between prokaryotes and eukaryotes and how they evolved throughout life history.

Acknowledgements We thank two anonymous reviewers for insightful comments.

Authors' contributions Conceptualization: KB, SG, FSP, FC, CCC; Writing original draft preparation: SG, KB, CCC; Writing-review and editing: SG, KB, CCC, FSP, FC, MG; Figures: SG, CCC, KB. Funding acquisition: KB. All authors read and approved the final manuscript.

Funding This work was supported by the French National Research Agency (HARLEY: ANR-19-CE44-0017), which supported discussion meetings and work about intracellular biomineralization and the Action Transversale du Muséum (ATM, MNHN), which supported the acquisition of microscopy data on intracellular biomineralization and publication fees. Sigrid Görgen's PhD was supported by the program Interfaces pour le vivant from Sorbonne University.

Availability of data and materials Not applicable.

Ethics approval and consent to participate Not applicable.

Consent for publication Not applicable.

Competing interests Not applicable.

Open Access This article is licensed under a Creative Commons Attribution 4.0 International License, which permits use, sharing, adaptation, distribution and reproduction in any medium or format, as long as you give appropriate credit to the original author(s) and the source, provide a link to the Creative Commons licence, and indicate if changes were made. The images or other third party material in this article are included in the article's Creative Commons licence, unless indicated otherwise in a credit line to the material. If material is not included in the article's Creative Commons licence and your intended use is not permitted by statutory regulation or exceeds the permitted use, you will need to obtain permission directly from the copyright holder. To view a copy of this licence, visit http://creativecommons.org/licenses/by/4.0/.

\section{References}

1. Gadd GM. Metals, minerals and microbes: geomicrobiology and bioremediation. Microbiology. 2010;156:609-43.

2. Kenward PA, Goldstein RH, González LA, Roberts JA. Precipitation of low-temperature dolomite from an anaerobic microbial consortium: the role of methanogenic Archaea. Geobiology. 2009;7:556-65.

3. Ehrenberg CG. Die Infusionsthierchen als vollkommene Organismen: ein Blick in das tiefere organische Leben der Natur : nebst einem Atlas von vierundsechszig colorirten Kupfertafeln, gezeichnet vom Verfasser. Leipzig: Voss; 1838. doi:https://doi.org/10.3931/e-rara-12412.

4. Schewiakoff W. Uber einen neuen bakteriennähnlichen Organismus des Süßwassers. Heidelberg: Habilitationsschrift; 1893.

5. Nadson G. Microorganisms as geological agents (Russian). Works Investig Slavian Miner Waters St Petersburg. 1903.

6. Drew GH. The action of some denitrifying bacteria in tropical and temperate seas, and the bacterial precipitation of calcium carbonate in the sea. J Mar Biol Assoc UK. 1911;9:142-55.

7. Kalkowsky E. Oolith und Stromatolith im norddeutschen Buntsandstein. Z Dtsch Geol Ges. 1908, p 68-125. 
8. Saghaï A, Zivanovic Y, Moreira D, Benzerara K, Bertolino P, Ragon M, et al. Comparative metagenomics unveils functions and genome features of microbialite-associated communities along a depth gradient: Comparative metagenomics of microbialites from Lake Alchichica. Environ Microbiol. 2016;18:4990-5004.

9. Boquet E. Production of calcite (calcium carbonate) crystals by soil bacteria is a general phenomenon. Nature. 1973;246:527-9.

10. Han Z, Wang J, Zhao H, Tucker ME, Zhao Y, Wu G, et al. Mechanism of biomineralization induced by Bacillus subtilis J2 and characteristics of the biominerals. Minerals. 2019;9:218.

11. Rodriguez-Navarro C, Jimenez-Lopez C, Rodriguez-Navarro A, Gonzalez-Muñoz MT, Rodriguez-Gallego M. Bacterially mediated mineralization of vaterite. Geochim Cosmochim Acta. 2007;71:1197-213.

12. Bundeleva IA, Shirokova LS, Bénézeth P, Pokrovsky OS, Kompantseva El, Balor S. Calcium carbonate precipitation by anoxygenic phototrophic bacteria. Chem Geol. 2012;291:116-31.

13. Pan J, Zhao H, Tucker ME, Zhou J, Jiang M, Wang Y, et al. Biomineralization of monohydrocalcite induced by the halophile Halomonas smyrnensis WMS-3. Minerals. 2019;9:632.

14. Li J, Margaret Oliver I, Cam N, Boudier T, Blondeau M, Leroy E, et al. Biomineralization patterns of intracellular carbonatogenesis in cyanobacteria: molecular hypotheses. Minerals. 2016;6:10.

15. Mehta N, Benzerara K, Kocar BD, Chapon V. Sequestration of radionuclides radium-226 and strontium-90 by cyanobacteria forming intracellular calcium carbonates. Environ Sci Technol. 2019;53:12639-47.

16. Warthmann R, van Lith Y, Vasconcelos C, McKenzie JA, Karpoff AM. Bacterially induced dolomite precipitation in anoxic culture experiments. Geology. 2000;28:1091-4.

17. Lamérand C, Shirokova LS, Bénézeth P, Rols J-L, Pokrovsky OS. Olivine dissolution and hydrous Mg carbonate and silicate precipitation in the presence of microbial consortium of photo-autotrophic and heterotrophic bacteria. Geochim Cosmochim Acta. 2020;268:123-41.

18. Sánchez-Román M, Fernández-Remolar D, Amils R, Sánchez-Navas A, Schmid T, Martin-Uriz PS, et al. Microbial mediated formation of Fe-carbonate minerals under extreme acidic conditions. Sci Rep. 2015;4:4767.

19. Zavarzin GA. Microbial geochemical calcium cycle. Microbiology. 2002;71:1-17.

20. Riding R. Cyanobacterial calcification, carbon dioxide concentrating mechanisms, and Proterozoic-Cambrian changes in atmospheric composition. Geobiology. 2006;4:299-316.

21 Altermann W, Kazmierczak J, Oren A, Wright DT. Cyanobacterial calcification and its rock-building potential during 3.5 billion years of Earth history. Geobiology. 2006;4:147-66.

22. Li J, Benzerara K, Bernard S, Beyssac O. The link between biomineralization and fossilization of bacteria: insights from field and experimental studies. Chem Geol. 2013;359:49-69.

23. Benzerara K, Menguy N. Looking for traces of life in minerals. CR Palevol. 2009;8:617-28.

24. Summons RE, Amend JP, Bish D, Buick R, Cody GD, Des Marais DJ, et al. Preservation of Martian organic and environmental records: final report of the Mars biosignature working group. Astrobiology. 2011;11:157-81.

25. Wacey D. Earliest evidence for life on Earth: an Australian perspective. Aust J Earth Sci. 2012;59:153-66.

26. Grotzinger JP, Knoll AH. Stromatolites in Precambrian carbonates: evolutionary mileposts or environmental dipsticks? Annu Rev Earth Planet Sci. 1999;27:313-58.

27. Hofmann HJ, Grey K, Hickman AH, Thorpe RI. Origin of 3.45 Ga coniform stromatolites in Warrawoona Group, Western Australia. GSA Bull. 1999;111:1256-62.

28. Warren LA, Maurice PA, Parmar N, Ferris FG. Microbially mediated calcium carbonate precipitation: implications for interpreting calcite precipitation and for solid-phase capture of inorganic contaminants. Geomicrobiol J. 2001;18:93-115.

29. McCutcheon J, Power IM, Harrison AL, Dipple GM, Southam G. A greenhouse-scale photosynthetic microbial bioreactor for carbon sequestration in magnesium carbonate minerals. Environ Sci Technol. 2014;48:9142-51.

30 Zhu T, Dittrich M. Carbonate precipitation through microbial activities in natural environment, and their potential in biotechnology: a review. Front Bioeng Biotechnol. 2016. https://doi.org/10.3389/fbioe.2016.00004.

31. Al-Thawadi SM. Ureolytic bacteria and calcium carbonate formation as a mechanism of strength enhancement of sand. J Adv Sci Eng Res. 2011;1:98-114.

32. Whiffin VS, van Paassen LA, Harkes MP. Microbial carbonate precipitation as a soil improvement technique. Geomicrobiol J. 2007;24:417-23.

33. Castanier S, Le Metayer-Levrel G, Perthuisot JP. Ca-carbonates precipitation and limestone genesis—the microbiogeologist point of view. Sediment Geol. 1999;126:9-23.

34 Machado e Portugal CR, Fonyo C, Machado CC, Meganck R, Jarvis T. Microbiologically induced calcite precipitation biocementation, green alternative for roads—is this the breakthrough? A critical review. J Clean Prod. 2020;262:121372.

35. Bhutange SP, Latkar MV. Microbially induced calcium carbonate precipitation in construction materials. J Mater Civ Eng. 2020;32:03120001.

36. Qin W, Wang C, Ma Y, Shen M, Li J, Jiao K, et al. Microbe-mediated extracellular and intracellular mineralization: environmental, industrial, and biotechnological applications. Adv Mater. 2020;32:1907833.

37. Castro-Alonso MJ, Montañez-Hernandez LE, Sanchez-Muñoz MA, Macias Franco MR, Narayanasamy R, Balagurusamy N. Microbially Induced Calcium Carbonate Precipitation (MICP) and its potential in bioconcrete: microbiological and molecular concepts. Front Mater. 2019;6:126.

38. Osinubi KJ, Eberemu AO, ljimdiya TS, Yakubu SE, Gadzama EW, Sani JE, et al. Review of the use of microorganisms in geotechnical engineering applications. Sn Appl Sci. 2020;2:207.

39. Yoreo JJD, Vekilov PG. Principles of crystal nucleation and growth. Rev Mineral Geochem. 2003;54:57-93.

40. Giuffre AJ, Hamm LM, Han N, De Yoreo JJ, Dove PM. Polysaccharide chemistry regulates kinetics of calcite nucleation through competition of interfacial energies. Proc Natl Acad Sci. 2013;110:9261-6.

41. Dupraz C, Reid RP, Braissant O, Decho AW, Norman RS, Visscher PT. Processes of carbonate precipitation in modern microbial mats. EarthSci Rev. 2009;96:141-62.

42 Gray ND. The unique role of intracellular calcification in the genus Achromatium. In: Shively JM, editor. Inclusions in prokaryotes. Berlin, Heidelberg: Springer; 2006. p. 299-309. 
43. Benzerara K, Skouri-Panet F, Li J, Férard C, Gugger M, Laurent T, et al. Intracellular Ca-carbonate biomineralization is widespread in cyanobacteria. Proc Natl Acad Sci. 2014;111:10933-8.

44 Mendes Monteiro J, Vogwill R, Bischoff K, Gleeson DB. Comparative metagenomics of microbial mats from hypersaline lakes at Rottnest Island (WA, Australia), advancing our understanding of the effect of mat community and functional genes on microbialite accretion. Limnol Oceanogr. 2020. https://doi.org/10.1002/Ino.11323.

45. Liu Z, Sun Y, Zhang Y, Qin S, Sun Y, Mao H, et al. Desert soil sequesters atmospheric $\mathrm{CO}_{2}$ by microbial mineral formation. Geoderma. 2020;361:114104.

46. DeFarge C, Trichet J, Jaunet A-M, Robert M, Tribble J, Sansone FJ. Texture of microbial sediments revealed by cryo-scanning electron microscopy. J Sediment Res. 1996;66:935-47.

47. Marin F, Bundeleva I, Takeuchi T, Immel F, Medakovic D. Organic matrices in metazoan calcium carbonate skeletons: composition, functions, evolution. J Struct Biol. 2016;196:98-106.

48. Warren LA, Ferris FG. Continuum between sorption and precipitation of Fe(III) on microbial surfaces. Environ Sci Technol. $1998 ; 32: 2331-7$.

49. Flemming $\mathrm{H}-\mathrm{C}$, Wingender J. The biofilm matrix. Nat Rev Microbiol. 2010;8:623-33.

50. Sheng G-P, Yu H-Q, Li X-Y. Extracellular polymeric substances (EPS) of microbial aggregates in biological wastewater treatment systems: a review. Biotechnol Adv. 2010;28:882-94.

51. Dupraz C, Visscher PT, Baumgartner LK, Reid RP. Microbe-mineral interactions: early carbonate precipitation in a hypersaline lake (Eleuthera Island, Bahamas). Sedimentology. 2004;51:745-65.

52. Benzerara K, Menguy N, López-García P, Yoon T-H, Kazmierczak J, Tyliszczak T, et al. Nanoscale detection of organic signatures in carbonate microbialites. Proc Natl Acad Sci. 2006;103:9440-5.

53 Costa OYA, Raaijmakers JM, Kuramae EE. Microbial extracellular polymeric substances: Ecological function and impact on soil aggregation. Front Microbiol. 2018. https://doi.org/10.3389/fmicb.2018.01636.

54 Rühmann B, Schmid J, Sieber V. Methods to identify the unexplored diversity of microbial exopolysaccharides. Front Microbiol. 2015. https://doi.org/10.3389/fmicb.2015.00565.

55. Couradeau E, Benzerara K, Moreira D, Gérard E, Kaźmierczak J, Tavera R, et al. Prokaryotic and eukaryotic community structure in field and cultured microbialites from the alkaline Lake Alchichica (Mexico). PLoS ONE. 2011. https://doi.org/10.1371/journal.pone.0028767.

56. Arp G, Thiel V, Reimer A, Michaelis W, Reitner J. Biofilm exopolymers control microbialite formation at thermal springs discharging into the alkaline Pyramid Lake, Nevada, USA. Sediment Geol. 1999;126:159-76.

57. Kawaguchi T, Decho AW. A laboratory investigation of cyanobacterial extracellular polymeric secretions (EPS) in influencing $\mathrm{CaCO}_{3}$ polymorphism. J Cryst Growth. 2002;240:230-5.

58. Arp G, Reimer A, Reitner J. Calcification in cyanobacterial biofilms of alkaline salt lakes. Eur J Phycol. 1999;34:393-403.

59. Luo J, Kong $\mathrm{F}$, Ma X. Role of aspartic acid in the synthesis of spherical vaterite by the $\mathrm{Ca}(\mathrm{OH})_{2}-\mathrm{CO}_{2}$ reaction. Cryst Growth Des. 2016;16:728-36.

60. Braissant O, Cailleau G, Dupraz C, Verrecchia AP. Bacterially induced mineralization of calcium carbonate in terrestrial environments: The role of exopolysaccharides and amino acids. J Sediment Res. 2003;73:485-90.

61. Borah BM, Singh AK, Ramesh A, Das G. Lactic acid bacterial extract as a biogenic mineral growth modifier. J Cryst Growth. 2009;311:2664-72.

62. Jittawuttipoka T, Planchon M, Spalla O, Benzerara K, Guyot F, Cassier-Chauvat C, et al. Multidisciplinary evidences that Synechocystis PCC 6803 exopolysaccharides operate in cell sedimentation and protection against salt and metal Stresses. PLoS ONE. 2013. https://doi. org/10.1371/journal.pone.0055564.

63. Ben Chekroun K, Rodriguez-Navarro C, Gonzalez-Munoz MT, Arias JM, Cultrone G, Rodriguez-Gallego M. Precipitation and growth morphology of calcium carbonate induced by Myxococcus xanthus: implications for recognition of bacterial carbonates. J Sediment Res. 2004;74:868-76.

64. González-Muñoz MT, Omar NB, Martínez-Cañamero M, Rodríguez-Gallego M, Galindo AL, Arias J. Struvite and calcite crystallization induced by cellular membranes of Myxococcus xanthus. J Cryst Growth. 1996;163:434-9.

65. Perito B, Marvasi M, Barabesi C, Mastromei G, Bracci S, Vendrell M, et al. A Bacillus subtilis cell fraction (BCF) inducing calcium carbonate precipitation: biotechnological perspectives for monumental stone reinforcement. J Cult Herit. 2014;15:345-51.

66. Yee N, Fein J. Cd adsorption onto bacterial surfaces: a universal adsorption edge? Geochim Cosmochim Acta. 2001;65:2037-42.

67. Fein JB, Martin AM, Wightman PG. Metal adsorption onto bacterial surfaces: development of a predictive approach. Geochim Cosmochim Acta. 2001;65:4267-73.

68. Obst M, Wehrli B, Dittrich M. $\mathrm{CaCO}_{3}$ nucleation by cyanobacteria: laboratory evidence for a passive, surface-induced mechanism. Geobiology. 2009;7:324-47.

69. Dittrich M, Sibler S. Cell surface groups of two picocyanobacteria strains studied by zeta potential investigations, potentiometric titration, and infrared spectroscopy. J Colloid Interface Sci. 2005;286:487-95.

70. Markai S, Andrès Y, Montavon G, Grambow B. Study of the interaction between europium (III) and Bacillus subtilis: fixation sites, biosorption modeling and reversibility. J Colloid Interface Sci. 2003;262:351-61.

71. Beveridge TJ, Murray RG. Sites of metal deposition in the cell wall of Bacillus subtilis. J Bacteriol. 1980;141:876-87.

72. Martinez RE, Gardés E, Pokrovsky OS, Schott J, Oelkers EH. Do photosynthetic bacteria have a protective mechanism against carbonate precipitation at their surfaces? Geochim Cosmochim Acta. 2010;74:1329-37.

73. Schultze-Lam S, Harauz G, Beveridge TJ. Participation of a cyanobacterial S layer in fine-grain mineral formation. J Bacteriol. 1992;174:7971-81.

74. Schultze-Lam S, Beveridge TJ. Physicochemical characteristics of the mineral-forming S-layer from the cyanobacterium Synechococcus strain GL24. Can J Microbiol. 1994;40:216-23.

75. Marvasi M, Casillas-Santiago LM, Henriquez T, Casillas-Martinez L. Involvement of etfA gene during $\mathrm{CaCO}_{3}$ precipitation in Bacillus subtilis biofilm. Geomicrobiol J. 2017;34:722-8.

76. Hintze PE, Nicholson WL. Single-spore elemental analyses indicate that dipicolinic acid-deficient Bacillus subtilis spores fail to accumulate calcium. Arch Microbiol. 2010;192:493-7. 
77. Sánchez-Román M, Rivadeneyra MA, Vasconcelos C, McKenzie JA. Biomineralization of carbonate and phosphate by moderately halophilic bacteria: mineral precipitation by halophilic bacteria. FEMS Microbiol Ecol. 2007;61:273-84.

78. Shiraki R, Brantley SL. Kinetics of near-equilibrium calcite precipitation at $100^{\circ} \mathrm{C}$ : an evaluation of elementary reaction-based and affinitybased rate laws. Geochim Cosmochim Acta. 1995;59:1457-71.

79. Morse JW, Arvidson RS, Lüttge A. Calcium carbonate formation and dissolution. Chem Rev. 2007;107:342-81.

80. van der Weijden $\mathrm{CH}$, van der Weijden RD. Calcite growth: rate dependence on saturation, on ratios of dissolved calcium and (bi)carbonate and on their complexes. J Cryst Growth. 2014;394:137-44.

81 White RAI, Chan AM, Gavelis GS, Leander BS, Brady AL, Slater GF, et al. Metagenomic analysis suggests modern freshwater microbialites harbor a distinct core microbial community. Front Microbiol. 2016. https://doi.org/10.3389/fmicb.2015.01531.

82. Verrecchia EP, Freytet $\mathrm{P}$, Verrecchia KE, Dumont J-L. Spherulites in calcrete laminar crusts; biogenic $\mathrm{CaCO}_{3}$ precipitation as a major contributor to crust formation. J Sediment Res. 1995;65:690-700.

83. Badger MR, Hanson D, Price GD. Evolution and diversity of $\mathrm{CO}_{2}$ concentrating mechanisms in cyanobacteria. Funct Plant Biol. $2002 ; 29: 161$.

84. Klanchui A, Cheevadhanarak S, Prommeenate $\mathrm{P}$, Meechai A. Exploring components of the $\mathrm{CO}_{2}$-concentrating mechanism in Alkaliphiliccyanobacteria through genome-based analysis. Comput Struct Biotechnol J. 2017;15:340-50.

85. Price GD, Badger MR, Woodger FJ, Long BM. Advances in understanding the cyanobacterial $\mathrm{CO}_{2}$-concentrating-mechanism (CCM): functional components, $C_{i}$ transporters, diversity, genetic regulation and prospects for engineering into plants. J Exp Bot. 2008;59:1441-61.

86. Waditee R, Hossain GS, Tanaka Y, Nakamura T, Shikata M, Takano J, et al. Isolation and functional characterization of $\mathrm{Ca}^{2+} / \mathrm{H}^{+}$antiporters from Cyanobacteria. J Biol Chem. 2004;279:4330-8.

87. Jiang H-B, Cheng H-M, Gao K-S, Qiu B-S. Inactivation of Ca2+/H+ exchanger in Synechocystis sp. strain PCC 6803 promotes cyanobacterial calcification by upregulating $\mathrm{CO}_{2}$-concentrating mechanisms. Appl Environ Microbiol. 2013;79:4048-55.

88. Effendi SSW, Ng I-S. The prospective and potential of carbonic anhydrase for carbon dioxide sequestration: a critical review. Process Biochem. 2019;87:55-65.

89 Bose $\mathrm{H}$, Satyanarayana T. Microbial carbonic anhydrases in biomimetic carbon sequestration for mitigating global warming: prospects and perspectives. Front Microbiol. 2017. https://doi.org/10.3389/fmicb.2017.01615.

90. Le Roy N, Jackson DJ, Marie B, Ramos-Silva P, Marin F. The evolution of metazoan a-carbonic anhydrases and their roles in calcium carbonate biomineralization. Front Zool. 2014;11:75.

91. Achal V, Pan X. Characterization of urease and carbonic anhydrase producing bacteria and their role in calcite precipitation. Curr Microbiol. 2011;62:894-902.

92. Smith KS, Ferry JG. Prokaryotic carbonic anhydrases. FEMS Microbiol Rev. 2000;24:335-66.

93. Capasso C, Supuran CT. An overview of the alpha-, beta- and gamma-carbonic anhydrases from Bacteria: can bacterial carbonic anhydrases shed new light on evolution of bacteria? J Enzyme Inhib Med Chem. 2015;30:325-32.

94. Supuran CT, Capasso C. New light on bacterial carbonic anhydrases phylogeny based on the analysis of signal peptide sequences. J Enzyme Inhib Med Chem. 2016;31:1254-60.

95 Srivastava S, Bharti RK, Verma PK, Thakur I. Cloning and expression of gamma carbonic anhydrase from Serratia sp. ISTD04 for sequestration of carbon dioxide and formation of calcite. Bioresour Technol. 2015;188:209-13.

96. Prabhu C, Wanjari S, Puri A, Bhattacharya A, Pujari R, Yadav R, et al. Region-specific bacterial carbonic anhydrase for biomimetic sequestration of carbon dioxide. Energy Fuels. 2011;25:1327-32.

97. Merz MUE. The biology of carbonate precipitation by cyanobacteria. Facies. 1992;26:81-101.

98 Martinez RE, Weber S, Grimm C. Effects of freshwater Synechococcus sp. cyanobacteria pH buffering on $\mathrm{CaCO}_{3}$ precipitation: implications for $\mathrm{CO}_{2}$ sequestration. Appl Geochem. 2016;75:76-89.

99. Garcia-Pichel F, Ramírez-Reinat E, Gao Q. Microbial excavation of solid carbonates powered by P-type ATPase-mediated transcellular $\mathrm{Ca}^{2+}$ transport. Proc Natl Acad Sci. 2010;107:21749-54.

100 Zhu Y, Ma N, Jin W, Wu S, Sun C. Genomic and transcriptomic insights into calcium carbonate biomineralization by marine Actinobacterium brevibacterium linens BS258. Front Microbiol. 2017. https://doi.org/10.3389/fmicb.2017.00602.

101. Berg IA. Ecological aspects of the distribution of different autotrophic $\mathrm{CO}_{2}$ fixation pathways. Appl Environ Microbiol. $2011 ; 77: 1925-36$.

102. Bosak T, Greene SE, Newman DK. A likely role for anoxygenic photosynthetic microbes in the formation of ancient stromatolites. Geobiology. 2007;5:119-26.

103. Michaelis W, Seifert R, Nauhaus K, Treude T, Thiel V, Blumenberg M, et al. Microbial reefs in the Black Sea fueled by anaerobic oxidation of methane. Science. 2002;297:1013-5.

104. Krause S, Aloisi G, Engel A, Liebetrau V, Treude T. Enhanced calcite dissolution in the presence of the aerobic methanotroph Methylosinus trichosporium. Geomicrobiol J. 2014;31:325-37.

105. Wittkop C, Swanner ED, Grengs A, Lambrecht N, Fakhraee M, Myrbo A, et al. Evaluating a primary carbonate pathway for manganese enrichments in reducing environments. Earth Planet Sci Lett. 2020;538:116201.

106 Smith GJ, Wrighton KC. Metagenomic approaches unearth methanotrophphylogenetic and metabolic diversity. Curr Issues Mol Biol. 2019. https://doi.org/10.21775/9781912530045.03.

107. Perito B, Biagiotti L, Daly S, Galizzi A, Tiano P, Mastromei G. Bacterial genes involved in calcite crystal precipitation. New York: Kluwer Academic/Plenum Publication; 2000.

108. Barabesi C, Galizzi A, Mastromei G, Rossi M, Tamburini E, Perito B. Bacillus subtilis gene cluster involved in calcium carbonate biomineralization. J Bacteriol. 2007;189:228-35.

109. Marvasi M, Visscher PT, Perito B, Mastromei G, Casillas-Martinez L. Physiological requirements for carbonate precipitation during biofilm development of Bacillus subtilis etfA mutant. FEMS Microbiol Ecol. 2010;71:341-50.

110 Veaudor T, Cassier-Chauvat C, Chauvat F. Genomics of urea transport and catabolism in cyanobacteria: biotechnological implications. Front Microbiol. 2019. https://doi.org/10.3389/fmicb.2019.02052.

111. Stocks-Fischer S, Galinat JK, Bang SS. Microbiological precipitation of $\mathrm{CaCO}_{3}$. Soil Biol Biochem. 1999;31:1563-71.

112. Hammes F, Boon N, de Villiers J, Verstraete W, Siciliano SD. Strain-specific ureolytic microbial calcium carbonate precipitation. Appl Environ Microbiol. 2003;69:4901-9. 
113. Bachmeier KL, Williams AE, Warmington JR, Bang SS. Urease activity in microbiologically-induced calcite precipitation. J Biotechnol. 2002;93:171-81.

114. Achal V, Mukherjee A, Basu PC, Reddy MS. Strain improvement of Sporosarcina pasteurii for enhanced urease and calcite production. J Ind Microbiol Biotechnol. 2009;36:981-8.

115. Oshiki M, Araki M, Hirakata Y, Hatamoto M, Yamaguchi T, Araki N. Ureolytic prokaryotes in soil: community abundance and diversity. Microbes Environ. 2018;33:230-3.

116. Harder Nielsen T, Bonde TA, Sørensen J. Significance of microbial urea turnover in N cycling of three Danish agricultural soils. FEMS Microbiol Ecol. 1998;25:147-57.

117. Krajewska B, Ureases I. Functional, catalytic and kinetic properties: a review. J Mol Catal B Enzym. 2009;59:9-21.

118. Mitchell A, Espinosa-Ortiz EJ, Parks SL, Phillips AJ, Cunningham AB, Gerlach R. Kinetics of calcite precipitation by ureolytic bacteria under aerobic and anaerobic conditions. Biogeosciences. 2019;16:2147-61.

119. Zhao X, Wang M, Wang H, Tang D, Huang J, Sun Y. Study on the remediation of Cd pollution by the biomineralization of urease-producing bacteria. Int J Environ Res Public Health. 2019;16:268.

120. Fisher KA, Yarwood SA, James BR. Soil urease activity and bacterial ureC gene copy numbers: effect of pH. Geoderma. 2017;285:1-8.

121. van Paassen LA, Daza CM, Staal M, Sorokin DY, van der Zon W, van Loosdrecht Mark CM. Potential soil reinforcement by biological denitrification. Ecol Eng. 2010;36:168-75.

122. Pham VP, van Paassen Leon A, van der Star WRL, Heimovaara TJ. Evaluating strategies to improve process efficiency of denitrificationbased MICP. J Geotech Geoenvironmental Eng. 2018;144:04018049.

123. Drew GH. On the precipitation of calcium carbonate in the sea by marine bacteria, and on the action of denitrifying bacteria in tropical and temperate seas. J Mar Biol Assoc UK. 1913;9:479-524.

124. Zumft WG. Cell biology and molecular basis of denitrification. Microbiol Mol Biol Rev. 1997;61:533-616.

125 Potter L, Angove H, Richardson D, Cole J. Nitrate reduction in the periplasm of gram-negative bacteria. Adv Microbial Physiol. 2001. https ://doi.org/10.1016/S0065-2911(01)45002-8.

126 van Spanning RJM, Richardson DJ, Ferguson SJ. Chapter 1-introduction to the biochemistry and molecular biology of denitrification. In: Bothe H, Ferguson SJ, Newton WE, editors. Biology of the Nitrogen Cycle. Amsterdam: Elsevier; 2007. p. 3-20.

127. Di Capua F, Pirozzi F, Lens PNL, Esposito G. Electron donors for autotrophic denitrification. Chem Eng J. 2019;362:922-37.

128. Boyd ES, Lange RK, Mitchell AC, Havig JR, Hamilton TL, Lafrenière MJ, et al. Diversity, abundance, and potential activity of nitrifying and nitrate-reducing microbial assemblages in a subglacial ecosystem. Appl Environ Microbiol. 2011;77:4778-87.

129. Mlewski EC, Pisapia C, Gomez F, Lecourt L, Soto Rueda E, Benzerara K, et al. Characterization of pustular mats and related Rivularia-rich laminations in oncoids from the Laguna Negra Lake (Argentina). Front Microbiol. 2018. https://doi.org/10.3389/fmicb.2018.00996.

130. Zhu X, Wang J, De Belie N, Boon N. Complementing urea hydrolysis and nitrate reduction for improved microbially induced calcium carbonate precipitation. Appl Microbiol Biotechnol. 2019;103:8825-38.

131. Hamdan N, Kavazanjian E, Rittmann BE, Karatas I. Carbonate mineral precipitation for soil improvement through microbial denitrification. Geomicrobiol J. 2017;34:139-46.

132. Lee KC, Rittmann BE. Effects of $\mathrm{pH}$ and precipitation on autohydrogenotrophic denitrification using the hollow-fiber membrane-biofilm reactor. Water Res. 2003;37:1551-6.

133. Karatas I. Microbiological improvement of the physical properties of soils_ProQuest. 2008. https://search.proquest.com/openview/ e911 bbd4881768c073e54a82df893526/1?pq-origsite=gscholar\&cbl=18750\&diss=y.

134. Ersan YC, de Belie N, Boon N. Microbially induced $\mathrm{CaCO}_{3}$ precipitation through denitrification: an optimization study in minimal nutrient environment. Biochem Eng J. 2015;101:108-18.

135. Rheinheimer G, Hegemann W, Raff J, Sekoulov I. Stickstoffkreislauf im Wasser. München: Oldenbourg Verlag; 1988.

136. Reyes C, Schneider D, Lipka M, Thürmer A, Böttcher ME, Friedrich MW. Nitrogen metabolism genes from temperate marine sediments. Mar Biotechnol. 2017;19:175-90.

137. Krause S, Liebetrau V, Loscher CR, Boehm F, Gorb S, Eisenhauer A, et al. Marine ammonification and carbonic anhydrase activity induce rapid calcium carbonate precipitation. Geochim Cosmochim Acta. 2018;243:116-32.

138. Rodriguez-Navarro C, Rodriguez-Gallego M, Ben Chekroun K, Gonzalez-Munoz MT. Conservation of ornamental stone by Myxococcus xanthus-induced carbonate biomineralization. Appl Environ Microbiol. 2003;69:2182-93.

139. Braissant O, Decho AW, Dupraz C, Glunk C, Przekop KM, Visscher PT. Exopolymeric substances of sulfate-reducing bacteria: Interactions with calcium at alkaline $\mathrm{pH}$ and implication for formation of carbonate minerals. Geobiology. 2007;5:401-11.

140. Gallagher KL, Dupraz C, Visscher PT. Two opposing effects of sulfate reduction on carbonate precipitation in normal marine, hypersaline, and alkaline environments: COMMENT. Geology. 2014;42:e313-4.

141. Aloisi G. The calcium carbonate saturation state in cyanobacterial mats throughout Earth's history. Geochim Cosmochim Acta. 2008;72:6037-60.

142. Visscher PT, Reid RP, Bebout BM, Hoeft SE, Macintyre IG, Thompson JA. Formation of lithified micritic laminae in modern marine stromatolites (Bahamas): the role of sulfur cycling. Am Min. 1998;83:1482-93.

143. Himmler T, Smrzka D, Zwicker J, Kasten S, Shapiro RS, Bohrmann G, et al. Stromatolites below the photic zone in the northern Arabian Sea formed by calcifying chemotrophic microbial mats. Geology. 2018;46:339-42.

144 Domínguez DC. Calcium signaling in prokaryotes. Calcium Signal Transduction. 2018. https://doi.org/10.5772/intechopen.78546.

145. Norris V, Grant S, Freestone P, Canvin J, Sheikh FN, Toth I, et al. Calcium signalling in bacteria. J Bacteriol. 1996;178:3677-82.

146. Hammes F, Verstraete W. Key roles of $\mathrm{pH}$ and calcium metabolism in microbial carbonate precipitation. Rev Environ Sci Biotechnol. 2002;1:3-7.

147. McConnaughey TA, Whelan JF. Calcification generates protons for nutrient and bicarbonate uptake. Earth-Sci Rev. 1997;42:95-117.

148. Banks ED, Taylor NM, Gulley J, Lubbers BR, Giarrizzo JG, Bullen HA, et al. Bacterial calcium carbonate precipitation in cave environments: a function of calcium homeostasis. Geomicrobiol J. 2010;27:444-54.

149 Lisle JT, Robbins LL. Viral lysis of photosynthesizing microbes as a mechanism for calcium carbonate nucleation in seawater. Front Microbiol. 2016. https://doi.org/10.3389/fmicb.2016.01958. 
150. Xu H, Peng X, Bai S, Ta K, Yang S, Liu S, et al. Precipitation of calcium carbonate mineral induced by viral lysis of cyanobacteria: evidence from laboratory experiments. Biogeosciences. 2019;16:949-60.

151 Gray N, Head I. The family achromatiaceae. In: Rosenberg E, Dong EF, Lory S, Stackebrandt E, Thompson F, editors. The prokaryotes. Berlin, Heidelberg: Springer; 2014. p. 1-14.

152. Salman V, Yang T, Berben T, Klein F, Angert E, Teske A. Calcite-accumulating large sulfur bacteria of the genus Achromatium in Sippewissett Salt Marsh. Isme J. 2015;9:2503-14.

153 Head IM, Gray ND, Howarth R, Pickup RW, Clarke KJ, Jones JG. Achromatium oxaliferum understanding the unmistakable. Adv Microbial Ecol. 2000. https://doi.org/10.1007/978-1-4615-4187-5_1.

154. Schorn S, Salman-Carvalho V, Littmann S, lonescu D, Grossart H-P, Cypionka H. Cell architecture of the giant sulfur bacterium Achromatium oxaliferum: extra-cytoplasmic localization of calcium carbonate bodies. FEMS Microbiol Ecol. 2020;96:200.

155 Mansor M, Hamilton TL, Fantle MS, Macalady J. Metabolic diversity and ecological niches of Achromatium populations revealed with single-cell genomic sequencing. Front Microbiol. 2015. https://doi.org/10.3389/fmicb.2015.00822.

156. Yang T, Teske A, Ambrose W, Salman-Carvalho V, Bagnell R, Nielsen LP. Intracellular calcite and sulfur dynamics of Achromatium cells observed in a lab-based enrichment and aerobic incubation experiment. Antonie Van Leeuwenhoek. 2019;112:263-74.

157. Couradeau E, Benzerara K, Gerard E, Moreira D, Bernard S, Brown GE, et al. An early-branching microbialitecyanobacterium forms intracellular carbonates. Science. 2012;336:459-62.

158. Moreira D, Tavera R, Benzerara K, Skouri-Panet F, Couradeau E, Gérard E, et al. Description of Gloeomargaritalithophora gen. nov., sp. nov., a thylakoid-bearing basal-branching cyanobacterium with intracellular carbonates, and proposal for Gloeomargaritales ord. nov. Int J Syst Evol Microbiol. 2017;67:653-8.

159. Ponce-Toledo RI, Deschamps P, López-García P, Zivanovic Y, Benzerara K, Moreira D. An early-branching freshwater cyanobacterium at the origin of plastids. Curr Biol. 2017;27:386-91.

160. De Wever A, Benzerara K, Coutaud M, Caumes G, Poinsot M, Skouri-Panet F, et al. Evidence of high Ca uptake by cyanobacteria forming intracellular $\mathrm{CaCO}_{3}$ and impact on their growth. Geobiology. 2019;17:676-90.

161 Ragon M, Benzerara K, Moreira D, Tavera R, López-García P. 16S rDNA-based analysis reveals cosmopolitan occurrence but limited diversity of two cyanobacterial lineages with contrasted patterns of intracellular carbonate mineralization. Front Microbiol. 2014. https://doi. org/10.3389/fmicb.2014.00331.

162. Blondeau M, Sachse M, Boulogne C, Gillet C, Guigner J-M, Skouri-Panet F, et al. Amorphous calcium carbonate granules form within an intracellular compartment in calcifying cyanobacteria. Front Microbiol. 2018;9:1768.

163. Stephens CJ, Ladden SF, Meldrum FC, Christenson HK. Amorphous calcium carbonate is stabilized in confinement. Adv Funct Mater. 2010;20:2108-15.

164. Cam N, Georgelin T, Jaber M, Lambert J-F, Benzerara K. In vitro synthesis of amorphous Mg-, Ca-, Sr- and Ba-carbonates: what do we learn about intracellular calcification by cyanobacteria? Geochim Cosmochim Acta. 2015;161:36-49.

165. Cam N, Benzerara K, Georgelin T, Jaber M, Lambert J-F, Poinsot M, et al. Cyanobacterial formation of intracellular Ca-carbonates in undersaturated solutions. Geobiology. 2018;16:49-61.

166. Cam N, Benzerara K, Georgelin T, Jaber M, Lambert J-F, Poinsot M, et al. Selective uptake of alkaline earth metals by cyanobacteria forming intracellular carbonates. Environ Sci Technol. 2016;50:11654-62.

167. Blondeau M, Benzerara K, Ferard C, Guigner J-M, Poinsot M, Coutaud M, et al. Impact of the cyanobacterium Gloeomargarita lithophora on the geochemical cycles of Sr and Ba. Chem Geol. 2018;483:88-97.

168. Miot J, Jézéquel D, Benzerara K, Cordier L, Rivas-Lamelo S, Skouri-Panet F, et al. Mineralogical diversity in Lake Pavin: connections with water column chemistry and biomineralization processes. Minerals. 2016;6:24.

169. Simkiss K. Biomineralization and detoxification. Calcif Tissue Res. 1977;24:199-200.

170. Anderson S, Appanna V, Huang J, Viswanatha T. A novel role for calcite in calcium homeostasis. Febs Lett. 1992;308:94-6.

171. Obst M, Dynes JJ, Lawrence JR, Swerhone GDW, Benzerara K, Karunakaran C, et al. Precipitation of amorphous CaCO3 (aragonite-like) by cyanobacteria: a STXM study of the influence of EPS on the nucleation process. Geochim Cosmochim Acta. 2009;73:4180-98.

172 Pronina NA, Kupriyanova EV, Igamberdiev AU. Photosynthetic carbon metabolism and $\mathrm{CO}_{2}$-concentrating mechanism of cyanobacteria. In: Hallenbeck PC, editor. Modern topics in the phototrophic prokaryotes: metabolism, bioenergetics, and omics. Cham: Springer International Publishing; 2017. p. 271-303.

Publisher's Note Springer Nature remains neutral with regard to jurisdictional claims in published maps and institutional affiliations. 